Prepared in cooperation with the Citizen Potawatomi Nation

\title{
Summary of U.S. Geological Survey Studies Conducted in Cooperation with the Citizen Potawatomi Nation, Central Oklahoma, 2011-14
}

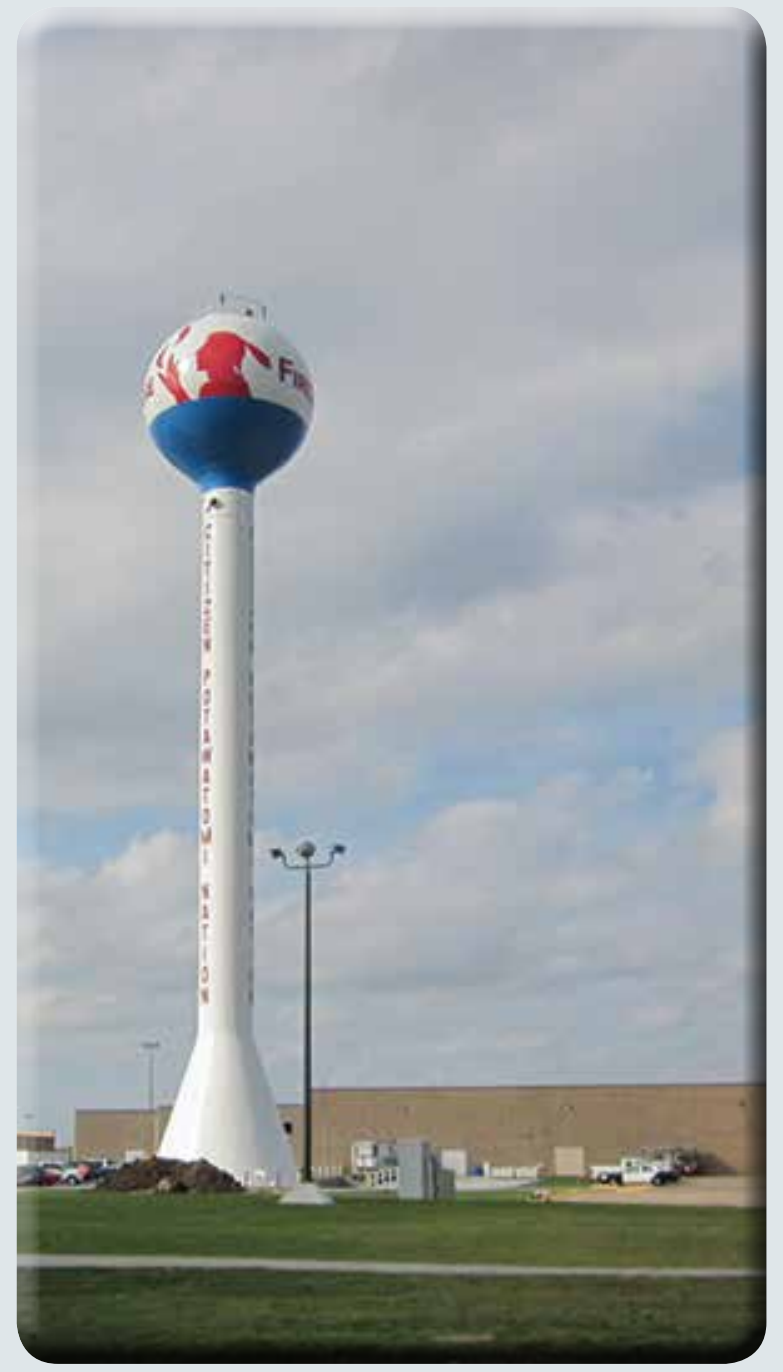

Scientific Investigations Report 2015-5182 
Cover, Water tower located in the Citizen Potawatomi Nation Tribal Jurisdictional Area, Shawnee, Oklahoma. Photograph by Michael Dotson, Citizen Potawatomi Nation. 


\section{Summary of U.S. Geological Survey Studies Conducted in Cooperation with the Citizen Potawatomi Nation, Central Oklahoma, 2011-14}

By William J. Andrews, Carol J. Becker, Derek W. Ryter, and S. Jerrod Smith

Prepared in cooperation with the Citizen Potawatomi Nation

Scientific Investigations Report 2015-5182 


\title{
U.S. Department of the Interior SALLY JEWELL, Secretary
}

\section{U.S. Geological Survey Suzette M. Kimball, Director}

\author{
U.S. Geological Survey, Reston, Virginia: 2016
}

For more information on the USGS - the Federal source for science about the Earth, its natural and living resources, natural hazards, and the environment-visit http://www.usgs.gov or call 1-888-ASK-USGS.

For an overview of USGS information products, including maps, imagery, and publications, visit http://www.usgs.gov/pubprod/.

Any use of trade, firm, or product names is for descriptive purposes only and does not imply endorsement by the U.S. Government.

Although this information product, for the most part, is in the public domain, it also may contain copyrighted materials as noted in the text. Permission to reproduce copyrighted items must be secured from the copyright owner.

Suggested citation:

Andrews, W.J., Becker, C.J., Ryter, D.W., and Smith, S.J., 2016, Summary of U.S. Geological Survey studies conducted in cooperation with the Citizen Potawatomi Nation, central Oklahoma, 2011-14: U.S. Geological Survey Scientific Investigations Report 2015-5182, 22 p., http://dx.doi.org/10.3133/sir20155182.

ISSN 2328-031X (print)

ISSN 2328-0328 (online) 


\section{Acknowledgments}

The authors thank Jim Collard, Kelley Francen, Shawn Howard, Richard Kunze, Kurtis Silas, and Karen Fulbright of the Citizen Potawatomi Nation for providing support and advice for the retrospective analysis of data, water-quality sample collection and analysis, groundwater modeling, and measurement of groundwater and surface-water relations. Thanks are expressed to the Administration for Native Americans of the U.S. Department of Health and Human Services for providing support for the projects conducted in cooperation with the Citizen Potawatomi Nation. We also are grateful to the many landowners who allowed access to their properties for collection of water samples. 



\section{Contents}

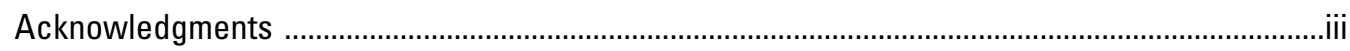

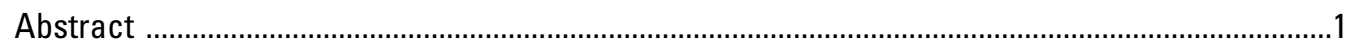

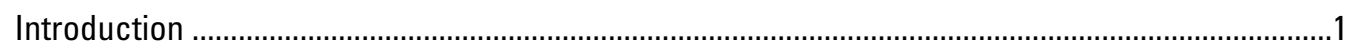

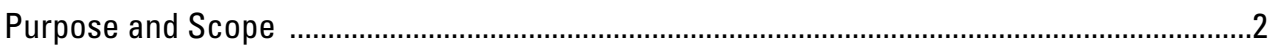

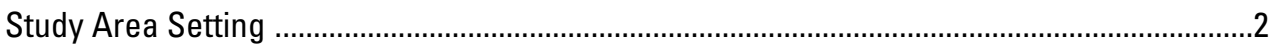

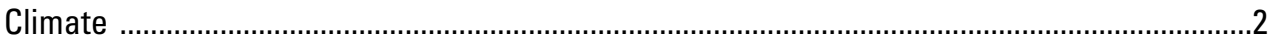

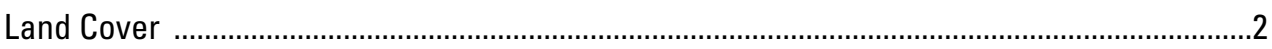

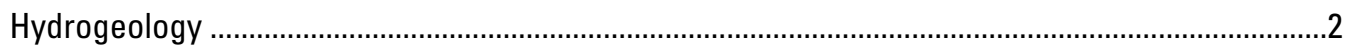

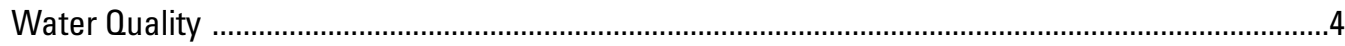

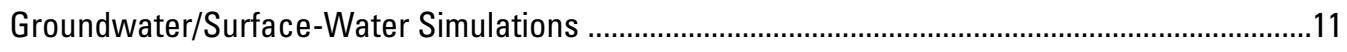

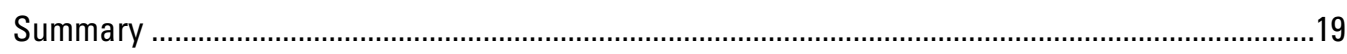

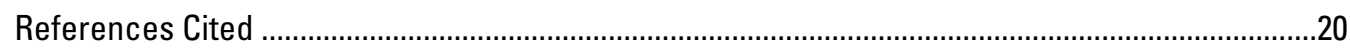

\section{Figures}

1. Map showing land cover in the Citizen Potawatomi Nation Tribal Jurisdictional Area, central Oklahoma, 2006

2. Graph showing annual mean streamflow at four long-term streamflow-gaging stations in central Oklahoma, October 1984 through September 2011.

3. Map showing surficial geology and locations of 4 stream sites and 30 wells sampled in and near the Citizen Potawatomi Nation Tribal Jurisdictional Area, central Oklahoma, 2012-13

4. Graphs showing nutrient concentrations measured in water samples collected at four stream sites in central Oklahoma, 2012-13, in relation to streamflow ...

5. Graphs showing number of detections of 69 organic compounds measured in water samples collected at 4 stream sites in central Oklahoma, 2012-13, with streamflow and of categories that include fecal indicators and plant sterols, polycyclic aromatic hydrocarbons, and 5 categories of synthetic organic compounds: detergent metabolites, industrial compounds, pesticides, personal care products, and fire retardants

6. Map showing location of the Citizen Potawatomi Nation Tribal Jurisdictional Area, hydrological features, and the Central Oklahoma and alluvial aquifers in central Oklahoma

7. Map showing Citizen Potawatomi Nation numerical groundwater-flow model active area with the 1986-87 potentiometric surface, steady-state head residuals, locations of model features, and the inset model domain for the Citizen Potawatomi Nation Tribal Jurisdictional Area in central Oklahoma

8. Graph showing transient measured groundwater heads and simulated groundwater heads for the Citizen Potawatomi Nation numerical groundwaterflow model, central Oklahoma

9. Graphs showing simulated and estimated streamflows for North Canadian River streamflow-gaging stations, 1988-2009 
10. Map showing inset model active area, top active layer, and boundary condition cells and locations of economic development zones simulated for sustainable yields, Citizen Potawatomi Nation Tribal Jurisdictional Area, central Oklahoma

11. Map showing Groundwater Management Process managed wells, optimized pumping rates, and resulting effects on induced infiltration by stream reach number at the Iron Horse Industrial Park, Citizen Potawatomi Nation Tribal Jurisdictional Area, central Oklahoma

12. Graph showing normal streamflow and streamflow during a simulated drought from 1990 to 2000 at the North Canadian River at Shawnee, Oklahoma, streamflow-gaging station, with percent change during and after the simulated drought

\section{Tables}

1. Stream-site information and land use and land cover in the upstream drainage basins of four stream sites sampled in and near the Citizen Potawatomi Nation Tribal Jurisdictional Area, central Oklahoma, 2012-13

2. Characteristics of 30 wells sampled in and near the Citizen Potawatomi Nation Tribal Jurisdictional Area, central Oklahoma, 2012-13 


\section{Conversion Factors}

Inch/Pound to International System of Units

\begin{tabular}{|c|c|c|}
\hline Multiply & By & To obtain \\
\hline \multicolumn{3}{|c|}{ Length } \\
\hline inch (in.) & 2.54 & centimeter $(\mathrm{cm})$ \\
\hline foot (ft) & 0.3048 & $\operatorname{meter}(\mathrm{m})$ \\
\hline mile (mi) & 1.609 & kilometer $(\mathrm{km})$ \\
\hline \multicolumn{3}{|c|}{ Area } \\
\hline acre & 4,047 & square meter $\left(\mathrm{m}^{2}\right)$ \\
\hline acre & 0.004047 & square kilometer $\left(\mathrm{km}^{2}\right)$ \\
\hline square mile $\left(\mathrm{mi}^{2}\right)$ & 259.0 & hectare (ha) \\
\hline square mile $\left(\mathrm{mi}^{2}\right)$ & 2.590 & square kilometer $\left(\mathrm{km}^{2}\right)$ \\
\hline \multicolumn{3}{|c|}{ Volume } \\
\hline gallon (gal) & 3.785 & liter (L) \\
\hline cubic foot $\left(\mathrm{ft}^{3}\right)$ & 0.02832 & cubic meter $\left(\mathrm{m}^{3}\right)$ \\
\hline acre-foot (acre-ft) & 1,233 & cubic meter $\left(\mathrm{m}^{3}\right)$ \\
\hline \multicolumn{3}{|c|}{ Flow rate } \\
\hline cubic foot per second $\left(\mathrm{ft}^{3} / \mathrm{s}\right)$ & 0.02832 & cubic meter per second $\left(\mathrm{m}^{3} / \mathrm{s}\right)$ \\
\hline gallon per minute (gal/min) & 0.06309 & liter per second $(\mathrm{L} / \mathrm{s})$ \\
\hline inch per year (in/yr) & 25.4 & millimeter per year $(\mathrm{mm} / \mathrm{yr})$ \\
\hline
\end{tabular}

Temperature in degrees Celsius $\left({ }^{\circ} \mathrm{C}\right)$ may be converted to degrees Fahrenheit $\left({ }^{\circ} \mathrm{F}\right)$ as ${ }^{\circ} \mathrm{F}=(1.8 \times$ $\left.{ }^{\circ} \mathrm{C}\right)+32$.

Temperature in degrees Fahrenheit $\left({ }^{\circ} \mathrm{F}\right)$ may be converted to degrees Celsius $\left({ }^{\circ} \mathrm{C}\right)$ as ${ }^{\circ} \mathrm{C}=\left({ }^{\circ} \mathrm{F}-\right.$ 32) / 1.8 .

\section{Datum}

Vertical coordinate information is referenced to the North American Vertical Datum of 1988 (NAVD 88).

Horizontal coordinate information is referenced to the North American Datum of 1983 (NAD 83).

Altitude, as used in this report, refers to distance above the vertical datum.

\section{Supplemental Information}

Specific conductance is given in microsiemens per centimeter at 25 degrees Celsius $(\mu \mathrm{S} / \mathrm{cm}$ at $\left.25^{\circ} \mathrm{C}\right)$.

Concentrations of chemical constituents in water are given in either milligrams per liter ( $\mathrm{mg} / \mathrm{L}$ ) or micrograms per liter $(\mu \mathrm{g} / \mathrm{L})$. 
viii

\section{Abbreviations}

EDZ economic development zone

ET evapotranspiration

MCL Maximum Contaminant Level

OWRB Oklahoma Water Resources Board

$\mathrm{R}^{2} \quad$ coefficient of determination

SMCL Secondary Maximum Contaminant Level

USGS U.S. Geological Survey 


\title{
Summary of U.S. Geological Survey Studies Conducted in Cooperation with the Citizen Potawatomi Nation, Central Oklahoma, 2011-14
}

\author{
By William J. Andrews, Carol J. Becker, Derek W. Ryter, and S. Jerrod Smith
}

\section{Abstract}

The U.S. Geological Survey conducted hydrologic studies and published three U.S. Geological Survey scientific investigations reports in cooperation with the Citizen Potawatomi Nation from 2011 to 2014 to characterize the quality and quantity of water resources. The study areas of those reports consisted of approximately 960 square miles in parts of three counties in central Oklahoma. This study area has multiple abundant sources of water, being underlain by three principal aquifers (alluvial/terrace, Central Oklahoma, and Vamoosa-Ada), being bordered by two major rivers (North Canadian and Canadian), and having several smaller drainages including the Little River in the central part of the study area and Salt Creek in the southeastern part of the study area. The Central Oklahoma aquifer (also referred to as the "Garber-Wellington aquifer") underlies approximately 3,000 square miles in central Oklahoma in parts of Cleveland, Logan, Lincoln, Oklahoma, and Pottawatomie Counties and much of the study area. Water from these aquifers is used for municipal, industrial, commercial, agricultural, and domestic supplies.

Much of the water in the study area is of good quality; however, in some parts of this area water quality was impaired by very hard surface water and groundwater, large chloride concentrations in some smaller streams, relatively large concentrations of nitrogen and phosphorus nutrients and large counts of fecal-indicator bacteria in the North Canadian River, and uranium concentrations that exceeded the U.S. Environmental Protection Agency Maximum Contaminant Level of 30 micrograms per liter for public water supplies in water samples collected from a small number of wells. Most stream-water samples collected from the Little River by the U.S. Geological Survey in 2012-13 had dissolved solids concentrations exceeding the U.S. Environmental Protection Agency Secondary Maximum Contaminant Level for public water supplies of 500 milligrams per liter. Larger numbers of organic compounds were measured in water samples collected from the North Canadian River than the Little River.
Numerical groundwater-flow models were created to characterize flow systems in aquifers underlying this study area and areas of particular interest within the study area. Those models were used to estimate sustainable groundwater yields from parts of the North Canadian River alluvial aquifer, characterize groundwater/surface-water interactions, and estimate the effects of a 10-year simulated drought on streamflows and water levels in alluvial and bedrock aquifers. Pumping of wells at the Iron Horse Industrial Park was estimated to cause negligible infiltration of water from the adjoining North Canadian River. A 10-year simulated drought of 50 percent of normal recharge was tested for the period 1990-2000. For this period, the total amount of groundwater in storage was estimated to decrease by 8.6 percent in the North Canadian River alluvial aquifer and approximately 0.2 percent in the Central Oklahoma aquifer, and groundwater flow to streams was estimated to decrease by 28-37 percent. This volume of groundwater loss showed that the Central Oklahoma aquifer is a bedrock aquifer that has relatively low rates of recharge from the land surface. The simulated drought decreased simulated streamflow, composed of base flow, in the North Canadian River at Shawnee, Okla., which did not recover to predrought conditions until the relatively wet year of 2007 after the simulated drought period.

\section{Introduction}

The Citizen Potawatomi Nation (CPN) was interested in better characterizing water resources associated with tribal-owned lands in central Oklahoma. The U.S. Geological Survey (USGS), in cooperation with the CPN, conducted studies of the occurrence and distribution of water resources, water quality, and simulations of groundwater and surfacewater systems in a 960-square-mile area of central Oklahoma from 2011 to 2014. 


\section{Purpose and Scope}

This report summarizes highlights of previously published USGS scientific investigations reports of historical hydrologic data and estimates of water resources and gaps in existing data (Andrews and others, 2013), groundwater and surface-water quality (Becker, 2014), and simulations of groundwater and surface-water flow systems (Ryter and others, 2015) in a 960-square-mile area of central Oklahoma. The CPN wanted these types of information to better understand the hydrologic resources of lands that their Nation owns and of surrounding areas.

\section{Study Area Setting}

The study area described in this report is in parts of Cleveland, Oklahoma, and Pottawatomie Counties in central Oklahoma (fig. 1). The study area has abundant water resources, being drained by the North Canadian River, which defines the northern border, the Canadian River, which defines the southern border, the Little River, which flows through the central part, and Salt Creek, which flows in the southeastern part of the study area (fig. 1). All major streams in the study area flow from west to east. The study area is underlain by unconsolidated alluvial and terrace aquifers along those rivers and by the consolidated Central Oklahoma and Vamoosa-Ada aquifers (Andrews and others, 2013).

\section{Climate}

The study area has a temperate continental climate, receiving an average of approximately 40 inches per year (in/yr) of precipitation from 1981 to 2010 and having approximately $50 \mathrm{in} / \mathrm{yr}$ of free-surface evaporation (Oklahoma Climatological Survey, 2011a, b). Precipitation typically occurs from March through June and from September through November (Oklahoma Climatological Survey, 2011b). Monthly average air temperatures from 1981 to 2010 ranged from 35.9 degrees Fahrenheit $\left({ }^{\circ} \mathrm{F}\right)$ in January to $81.5^{\circ} \mathrm{F}$ in July (Oklahoma Climatological Survey, 2011a).

\section{Land Cover}

The predominant types of land cover in the study area as of 2006 were deciduous forest and shrubs and natural grassland, which are most common in the central part of the study area (fig. 1; U.S. Geological Survey, 2012). Cultivated crops and pasture or hay were predominant landcover types on flatter land along major streams and in the southwestern part of the study area (fig. 1; U.S. Geological Survey, 2012).

\section{Hydrogeology}

Annual mean streamflows at three sites in the study area generally decreased from peaks in the late 1980s (fig. 2). Streamflows at four sites in the study area recently peaked in water year 2007-8 but declined to near long-term low flows by water year 2011 (fig. 2). A water year is the 12-month period October 1 through September 30 designated by the calendar year in which it ends.

Groundwater also is an important source of water in the study area. The principal aquifers in the study area are alluvial and terrace aquifers along the North Canadian and Canadian Rivers, referred to herein as "alluvial aquifers," and the Central Oklahoma aquifer, composed of the Garber Sandstone, Wellington Formation, and Chase, Council Grove, and Admire Groups (fig. 3). Alluvial aquifers are the thinnest aquifers in the area, generally being less than 100 feet (ft) thick, compared to thicknesses of several hundred to more than $1,000 \mathrm{ft}$ of bedrock aquifers underlying the study area (Andrews and others, 2013). Despite being relatively thin, alluvial aquifers in the study area produce some of the highest well yields, in some cases exceeding 1,000 gallons per minute (gal/min; Andrews and others 2013). The Central Oklahoma aquifer (also referred to as the "Garber-Wellington aquifer") underlies approximately 3,000 square miles in central Oklahoma in parts of Cleveland, Logan, Lincoln, Oklahoma, and Pottawatomie Counties and much of the study area. Wells completed in the Central Oklahoma aquifer, which underlies most of the area, typically produce $25-50 \mathrm{gal} / \mathrm{min}$ (Bingham and Moore, 1975). Wells completed in the Vamoosa-Ada aquifer, which underlies the Vanoss Formation in the easternmost part of the study area and is not a major aquifer (fig. 3), generally produce less than $25 \mathrm{gal} / \mathrm{min}$ (Bingham and Moore, 1975). Groundwater levels in the Central Oklahoma aquifer decreased from about $32 \mathrm{ft}$ below land surface in 1987 to $35.8 \mathrm{ft}$ below land surface in 2009 (Christenson and others, 1992; Mashburn and Magers, 2011). 


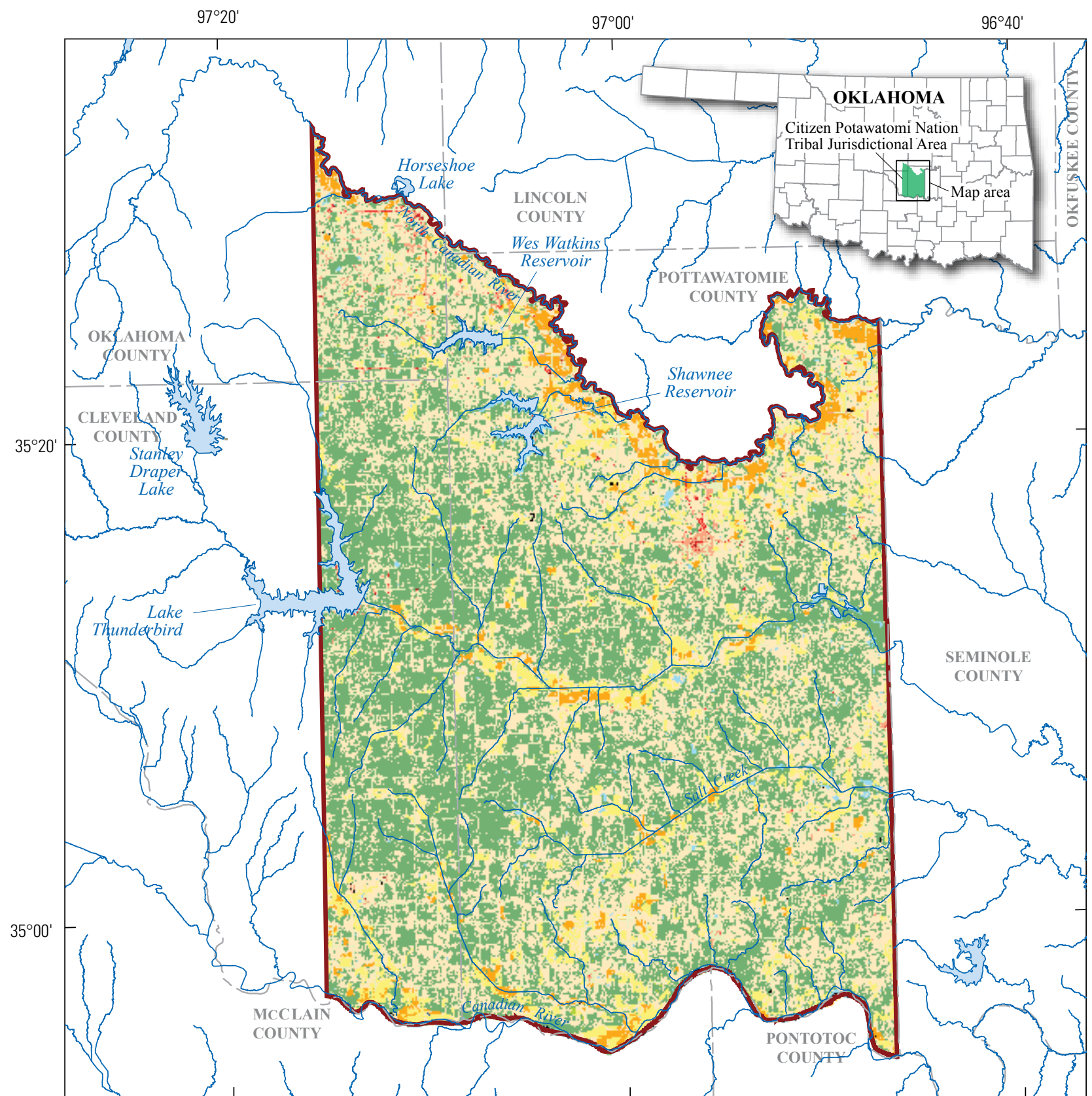

Base modified from U.S. Geological Survey digital data, 1983, 1:100,000

Universal Transverse Mercator, zone 14

North American Datum of 1983

Land-cover data from Multi-Resolution Land Characteristics Consortium National Land Cover Database (U.S. Geological Survey, 2012)

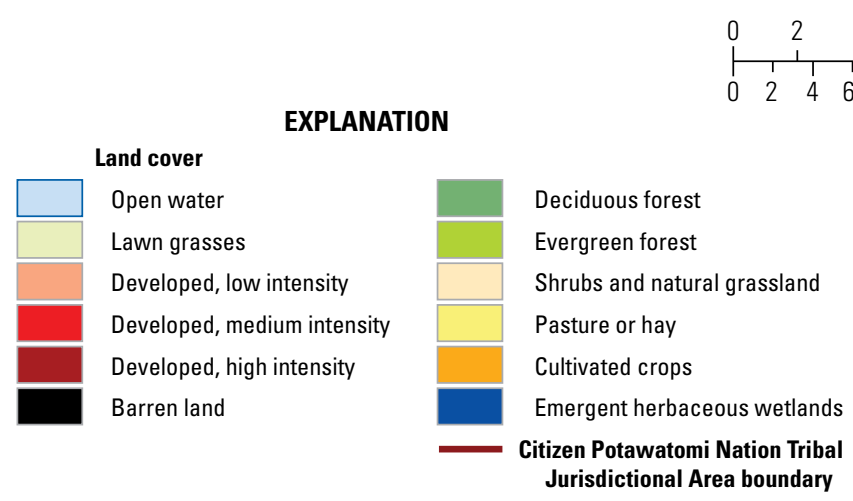

Figure 1. Land cover in the Citizen Potawatomi Nation Tribal Jurisdictional Area, central Oklahoma, 2006 (modified from Andrews and others, 2013). 


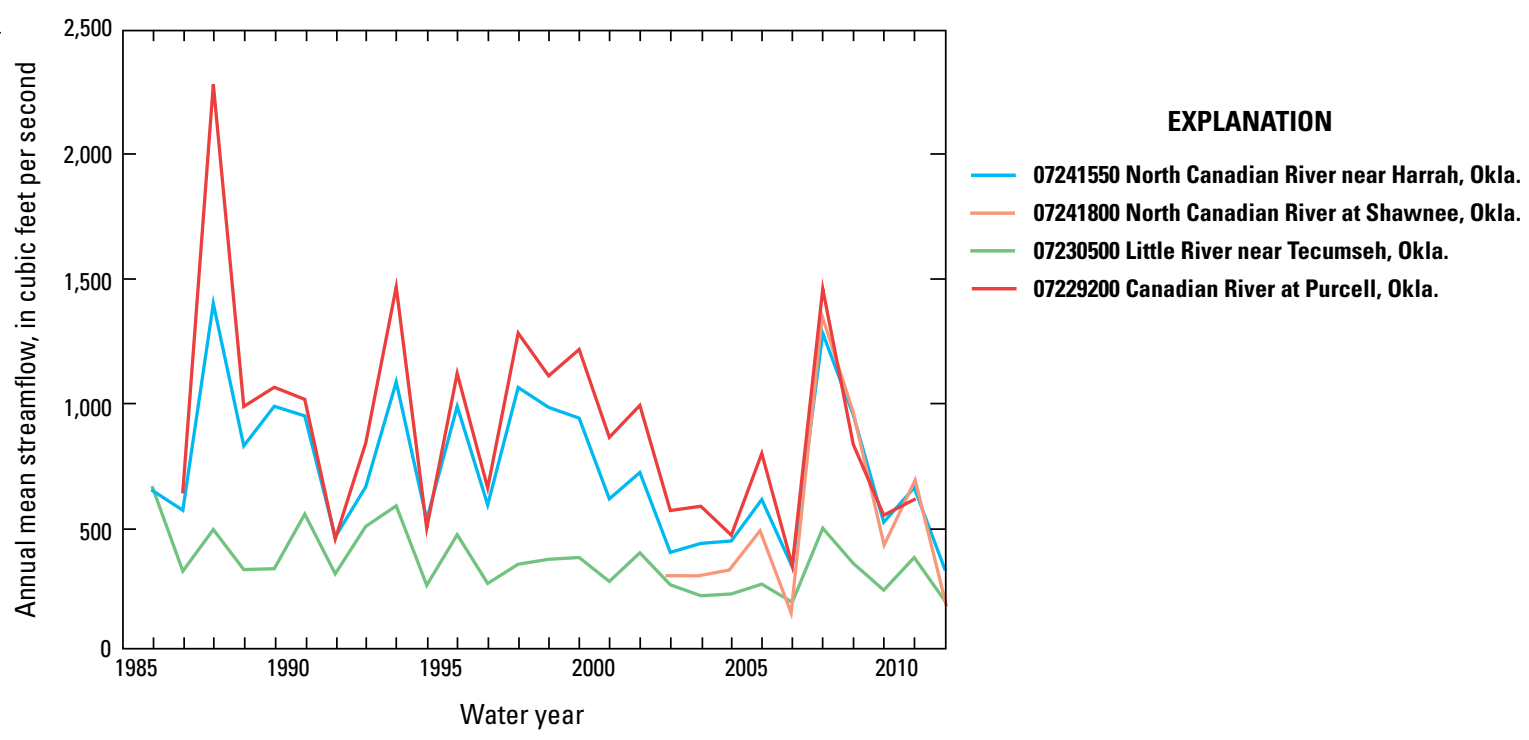

Figure 2. Annual mean streamflow at four long-term streamflow-gaging stations in central Oklahoma, October 1984 through September 2011 (modified from Andrews and others, 2013).

\section{Water Quality}

Retrospective analysis of water-quality data collected by the USGS and State and tribal agencies from 1985 to 2011 (Andrews and others, 2013) indicated the following general features about water quality in the study area:

1. Total dissolved solids concentrations in more than half of the surface-water samples collected in this area exceeded the U.S. Environmental Protection Agency (EPA) Secondary Maximum Contaminant Level (SMCL) of 500 milligrams per liter (mg/L; U.S. Environmental Protection Agency, 2011a). Numerous samples in the Salt Creek watershed in the southeastern part of the study area (fig. 3) had total dissolved solids concentrations greater than $1,000 \mathrm{mg} / \mathrm{L}$. Hardness, which commonly is positively correlated to total dissolved solids concentration, is an indication of the likelihood of water to form carbonate mineral deposits in pipes and boilers. More than three-quarters of the surface-water samples and most of the groundwater samples collected in this study area were very hard.

2. Chloride concentrations exceeded the EPA SMCL of $250 \mathrm{mg} / \mathrm{L}$ (U.S. Environmental Protection Agency, 2011a) in most surface-water samples collected in the Salt Creek watershed. Chloride concentrations in those samples also exceeded the Criterion Continuous Concentration set to protect aquatic life $(230 \mathrm{mg} / \mathrm{L}$; U.S. Environmental Protection Agency, 2002). Chloride concentrations exceeding that standard can contribute salty taste to water, elevate blood pressure, harm plants and aquatic biota, and increase corrosiveness of water to metal pipes (Wesson, 1969; Fadeeva, 1971; Maas, 1987; World Health Organization, 1996).

3. Total phosphorus concentrations in surface-water samples collected from the North Canadian River were greater than criteria set to minimize eutrophication (excessive growth of algae and other aquatic plants) in surface water, such as the $0.037 \mathrm{mg} / \mathrm{L}$ standard set for Scenic Rivers in northeast Oklahoma, and the $0.075 \mathrm{mg} / \mathrm{L}$ standard set by the State of Wisconsin for most streams in that state (State of Oklahoma, 2006; State of Wisconsin, 2010).

4. Numbers of fecal-coliform bacteria, which are associated with animal feces, in water samples collected at nine sites on the North Canadian River exceeded the primary contact standard of 200 colonies per 100 milliliters (geometric mean of 5 samples in 30 days; State of Oklahoma, 2006) in 10-70 percent of those samples.

5. Twenty to twenty-five percent of groundwater samples collected from alluvial aquifers and the Central Oklahoma aquifer were more acidic than the EPA SMCL for pH of 6.5 (U.S. Environmental Protection Agency, 2011a). That SMCL was set to minimize corrosion of metals from pipes.

6. Potassium, sodium, fluoride, and bicarbonate concentrations were significantly greater in water samples collected from the Vamoosa-Ada aquifer in the eastern edge of the study area than in samples from the other aquifers. Concentrations of these ions increased with well depths. 


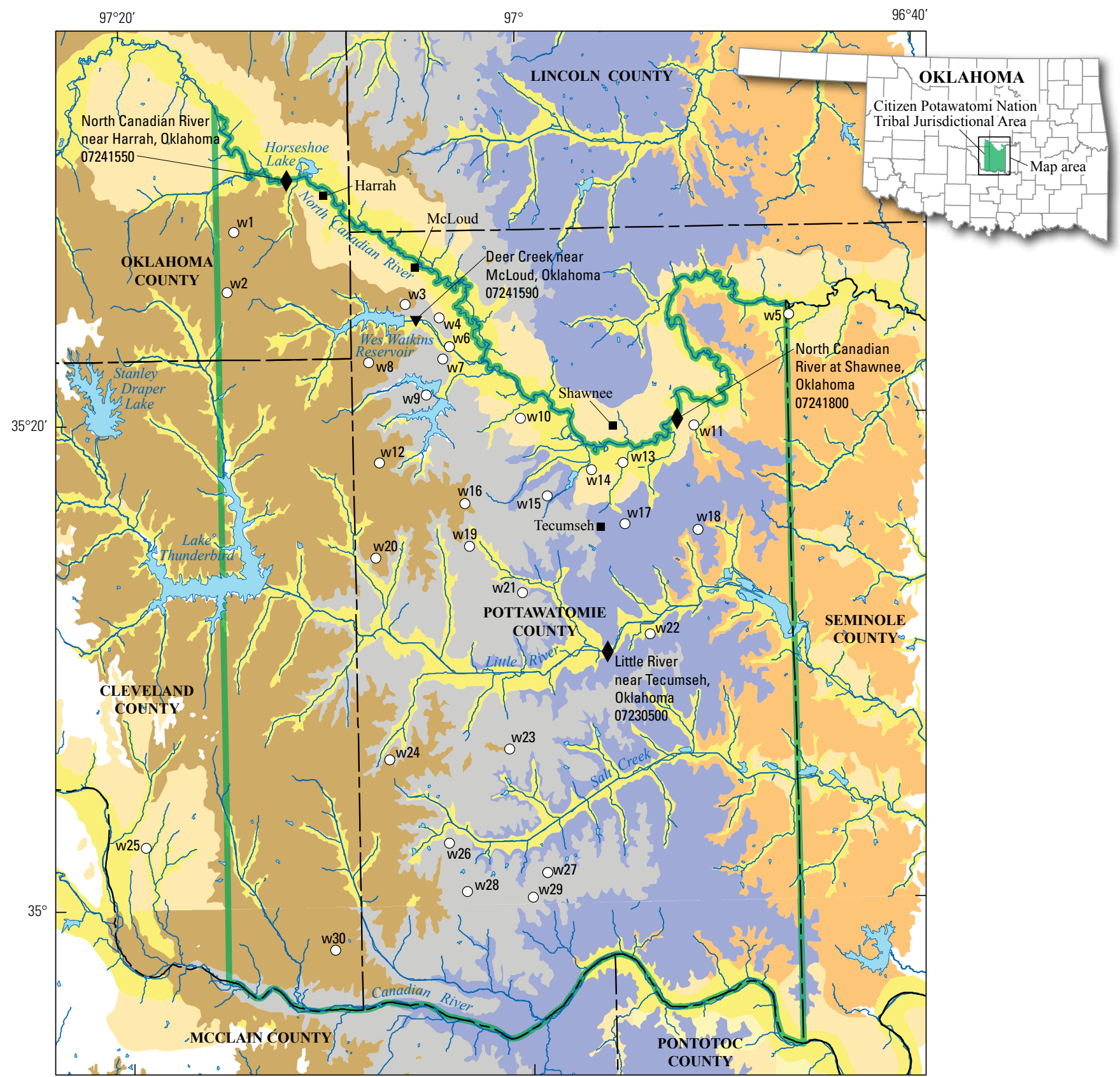

Base from U.S. Geological Survey digital data 1:100,000, 1983 Albers Equal-Area Conic projection, North American Datum of 1983

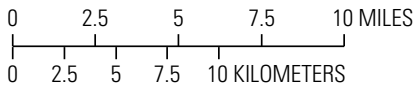

Geology from Lindberg (1987) and Bingham and Moore (1975)

\section{EXPLANATION}

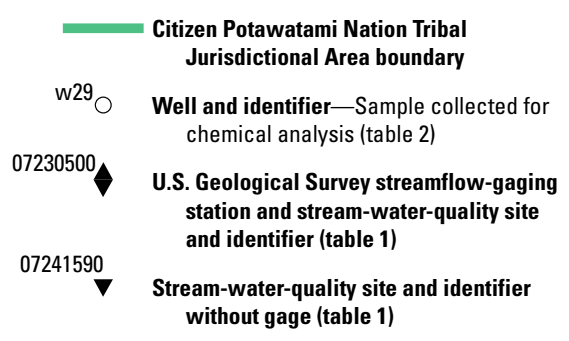

Quaternary-age geologic unit Terrace deposits

Alluvium

Permian-age geologic unit

Garber Sandstone

Wellington Formation

Chase, Council Grove, and Admire Groups (undivided)

\section{Pennsylvanian-age geologic unit}

Vanoss Formation

Figure 3. Surficial geology and locations of 4 stream sites and 30 wells sampled in and near the Citizen Potawatomi Nation Tribal Jurisdictional Area, central Oklahoma, 2012-13 (from Becker, 2014). 
Summary of USGS Studies Conducted in Cooperation with the CPN, Central Oklahoma, 2011-14

Becker (2014) provided an updated assessment of surface-water and groundwater quality; sampling described in that report was conducted for constituents that had not been analyzed in previous studies and in areas not previously sampled. A total of 4 stream sites were sampled repeatedly, and 30 wells were sampled once in the study area from 2012 to 2013 (Becker, 2014; tables 1 and 2). Water-quality data collected from those sites can be downloaded from the USGS National Water Information System (U.S. Geological Survey, 2015). Notable results from that report related to surface-water quality include the following:

1. The largest concentrations of total dissolved solids and chlorides were measured in stream-water samples collected at the Little River near Tecumseh, Okla., streamflow-gaging station. The EPA SMCL for total dissolved solids in drinking water of $500 \mathrm{mg} / \mathrm{L}$ was exceeded in 7 of 8 stream-water samples collected at that station. The 250-mg/L EPA SMCL for chloride was exceeded in 5 of the 8 stream-water samples collected at that station.

2. Median concentrations of total dissolved nitrogen were about an order of magnitude higher in stream-water samples collected at the two streamflow-gaging stations on the North Canadian River than concentrations in stream-water samples collected at the Little River near Tecumseh, Okla., streamflow-gaging station and the Deer Creek site (fig. 4). Median concentrations of total dissolved phosphorus were higher by about two orders of magnitude in stream-water samples collected at the two streamflow-gaging stations on the North Canadian River than concentrations in stream-water samples collected at the Little River near Tecumseh, Okla., streamflowgaging station and the Deer Creek site and typically exceeded previously described water-quality standards for total dissolved phosphorus in streams. Dissolved concentrations of total nitrogen, orthophosphorus, and total phosphorus were largest in stream-water samples collected at the two North Canadian River streamflow- gaging stations at low streamflows, indicating that wastewater effluent discharged upstream may have been a notable source of these nutrients.

3. Concentrations of most trace elements increased with increasing streamflow in stream-water samples collected at the two North Canadian River streamflowgaging stations, indicating that most trace elements are washed into the river by runoff from the land surface or resuspended from streambed sediments. Most trace-element concentrations were less than Maximum Contaminant Levels (MCLs) set for public drinkingwater supplies (U.S. Environmental Protection Agency, 2011b).

4. A greater number of organic compounds were detected in stream-water samples collected at the two streamflowgaging stations on the North Canadian River than in stream-water samples collected at the streamflow-gaging station on the Little River near Tecumseh, Okla., and the Deer Creek site (fig. 5).

Notable results from Becker (2014) related to groundwater quality include the following:

1. Groundwater in the study area was very hard, with a median concentration of $180 \mathrm{mg} / \mathrm{L}$ as calcium carbonate in water samples collected from the 30 wells. Dissolved solids concentrations exceeded the 500-mg/L SMCL in 9 of the 30 groundwater samples. Trace-element concentrations, except for uranium, did not exceed MCLs in the groundwater samples.

2. Two of the 30 groundwater samples had uranium concentrations exceeding the MCL of 30 micrograms per liter $(\mu \mathrm{g} / \mathrm{L})$ with concentrations of 79.5 and $31.1 \mu \mathrm{g} / \mathrm{L}$. Uranium concentrations were highest in water samples collected from wells completed in the Wellington Formation and the Chase, Council Grove, and Admire Groups in the southern and eastern parts of the study area. 
Table 1. Stream-site information and land use and land cover in the upstream drainage basins of four stream sites sampled in and near the Citizen Potawatomi Nation Tribal Jurisdictional Area, central Oklahoma, 2012-13 (from Becker, 2014).

[USGS, U.S. Geological Survey; $\mathrm{ft}^{3} / \mathrm{s}$, cubic feet per second; -, not applicable; streamflow is by calendar year; annual mean streamflow calculated for years with complete data only; streamflow represents continuous streamflow measured by real-time monitor]

\begin{tabular}{|c|c|c|c|c|c|c|}
\hline $\begin{array}{l}\text { USGS } \\
\text { streamflow- } \\
\text { gaging station } \\
\text { and number }\end{array}$ & $\begin{array}{l}\text { Upstream drainage } \\
\text { area/contributing } \\
\text { drainage area } \\
\text { (square miles) }\end{array}$ & $\begin{array}{c}\text { Annual mean } \\
\text { streamflow }\left(\mathrm{ft}^{3} / \mathrm{s}\right) \\
\text { (years of record) }^{\mathrm{a}}\end{array}$ & $\begin{array}{c}\text { Mean daily } \\
\text { streamflow } \\
\text { Jan. 1-Dec. 31, } 2012 \\
\left(\mathrm{ft}^{3} / \mathrm{s}\right)^{\mathrm{a}}\end{array}$ & $\begin{array}{c}\text { Lowest streamflow/highest } \\
\text { streamflow Jan. 1-Dec. 31, } 2012 \\
\left(\mathrm{ft}^{3} / \mathrm{s}\right)^{\mathrm{a}}\end{array}$ & $\begin{array}{l}\text { Information collected } \\
\text { during study }\end{array}$ & $\begin{array}{l}\text { Percentages of the three } \\
\text { largest land use and land } \\
\text { cover categories in the } \\
\text { upstream drainage basin }\end{array}$ \\
\hline $\begin{array}{l}\text { Little River near } \\
\text { Tecumseh, } \\
\text { Oklahoma } \\
(07230500)\end{array}$ & $463 / 463$ & $\begin{array}{c}143 \\
(1966 \text { to } 2013)\end{array}$ & 12.7 & $\begin{array}{l}0 \text { (July } 21 \text { through August 18)/1,260 } \\
\quad \text { (March 19) }\end{array}$ & $\begin{array}{l}8 \text { water-quality samples; } \\
8 \text { water-property } \\
\text { measurements; } \\
8 \text { streamflow } \\
\text { measurements }\end{array}$ & $\begin{array}{l}44 \text { percent deciduous forest; } \\
35 \text { percent pasture or hay; } \\
8 \text { percent lawn grasses }\end{array}$ \\
\hline $\begin{array}{l}\text { North Canadian } \\
\text { River near } \\
\text { Harrah, } \\
\text { Oklahoma } \\
(07241550)\end{array}$ & $13,775 / 10,278$ & $\begin{array}{c}488 \\
(1969 \text { to } 2011)\end{array}$ & 180 & 39 (November 11)/4,270 (March 20) & $\begin{array}{l}8 \text { water-quality samples; } \\
8 \text { water-property } \\
\text { measurements; } \\
8 \text { streamflow } \\
\text { measurements; real- } \\
\text { time measurements of } \\
\text { water properties and } \\
\text { streamflow }\end{array}$ & $\begin{array}{l}62 \text { percent pasture or hay; } \\
24 \text { percent cultivated } \\
\text { crops; } 6 \text { percent shrubs and } \\
\text { natural grassland }\end{array}$ \\
\hline $\begin{array}{l}\text { Deer Creek near } \\
\text { McLoud, } \\
\text { Oklahoma } \\
(07241590)\end{array}$ & 40 & Not gaged & - & - & $\begin{array}{l}3 \text { water-quality samples; } \\
3 \text { water-property } \\
\text { measurements; } \\
2 \text { streamflow } \\
\text { measurements }\end{array}$ & $\begin{array}{l}39 \text { percent pasture or hay; } \\
35 \text { percent deciduous } \\
\text { forest; } 12 \text { percent lawn } \\
\text { grasses }\end{array}$ \\
\hline $\begin{array}{l}\text { North Canadian } \\
\text { River at } \\
\text { Shawnee, } \\
\text { Oklahoma } \\
(07241800)\end{array}$ & $14,005 / 10,508$ & $\begin{array}{c}524 \\
(2002 \text { to } 2011)\end{array}$ & 246 & 30 (August 5)/4,860 (April 18) & $\begin{array}{l}8 \text { water-quality samples; } \\
8 \text { water-property } \\
\text { measurements; } \\
8 \text { streamflow } \\
\text { measurements }\end{array}$ & $\begin{array}{l}62 \text { percent pasture or hay; } \\
23 \text { percent cultivated crops; } \\
6 \text { percent shrubs and } \\
\text { natural grassland }\end{array}$ \\
\hline
\end{tabular}

${ }^{a}$ U.S. Geological Survey (2013).

bFry and others (2011). 


\section{Summary of USGS Studies Conducted in Cooperation with the CPN, Central Oklahoma, 2011-14}

Table 2. Characteristics of 30 wells sampled in and near the Citizen Potawatomi Nation Tribal Jurisdictional Area, central Oklahoma, 2012-13 (modified from Becker, 2014).

[ID, identifier; USGS, U.S. Geological Survey; NAVD 88, North American Vertical Datum of 1988; GBWG, Garber-Wellington aquifer; ALVM, alluvial aquifer; TTRC, terrace aquifer; CCGA, Chase, Council Grove, and Admire Groups; VNSS, Vanoss Formation]

\begin{tabular}{|c|c|c|c|c|c|}
\hline Well ID & $\begin{array}{c}\text { USGS } \\
\text { station ID }\end{array}$ & $\begin{array}{l}\text { Land surface altitude } \\
\text { (feet above NAVD 88) }\end{array}$ & $\begin{array}{c}\text { Well depth } \\
\text { (depth in feet } \\
\text { below land surface) }\end{array}$ & $\begin{array}{l}\text { Water } \\
\text { use }\end{array}$ & Aquifer \\
\hline w1 & 352755097141801 & 1,210 & 240 & Domestic & GBWG \\
\hline w2 & 352527097144201 & 1,244 & 120 & Domestic & GBWG \\
\hline w3 & 352449097054601 & 1,099 & 110 & Domestic & GBWG \\
\hline w4 & 352412097040301 & 1,093 & 170 & Domestic & GBWG \\
\hline w5 & 352407096462701 & 907 & 42 & Unused & ALVM \\
\hline w6 & 352303097033401 & 1,031 & 220 & Commercial & GBWG \\
\hline w7 & 352232097035501 & 1,073 & 60 & Domestic & TTRC \\
\hline w8 & 352226097073901 & 1,161 & 160 & Domestic & GBWG \\
\hline w9 & 352104097044701 & 1,101 & 200 & Domestic & GBWG \\
\hline w10 & 352002097000301 & 1,079 & 160 & Domestic & CCGA \\
\hline w11 & 351937096512201 & 993 & 100 & Domestic & VNSS \\
\hline w12 & 351819097071201 & 1,178 & 160 & Domestic & GBWG \\
\hline w13 & 351807096545801 & 991 & 80 & Industrial & ALVM \\
\hline w14 & 351751096563301 & 1,002 & 195 & Domestic & CCGA \\
\hline w15 & 351649096584801 & 1,077 & 90 & Domestic & CCGA \\
\hline w16 & 351634097025601 & 1,152 & 170 & Domestic & GBWG \\
\hline w17 & 351536096545501 & 1,072 & 165 & Domestic & CCGA \\
\hline w18 & 351518096511501 & 1,080 & 200 & Domestic & VNSS \\
\hline w19 & 351448097024501 & 1,092 & 160 & Domestic & GBWG \\
\hline w20 & 351422097072801 & 1,038 & 140 & Domestic & GBWG \\
\hline w21 & 351251097000801 & 1,013 & 220 & Domestic & GBWG \\
\hline w22 & 351103096534601 & 914 & 70 & Stock & ALVM \\
\hline w23 & 350624097005601 & 1,101 & 80 & Domestic & GBWG \\
\hline w24 & 350603097065901 & 1,117 & 176 & Domestic & GBWG \\
\hline w25 & 350236097191501 & 1,088 & 360 & Domestic & GBWG \\
\hline w26 & 350234097040401 & 1,032 & 80 & Domestic & GBWG \\
\hline w27 & 350117096591001 & 1,044 & 260 & Domestic & GBWG \\
\hline w28 & 350034097031201 & 1,103 & 141 & Domestic & GBWG \\
\hline w29 & 350017096595501 & 1,012 & 80 & Domestic & GBWG \\
\hline w30 & 345816097095101 & 1,102 & 200 & Domestic & GBWG \\
\hline
\end{tabular}



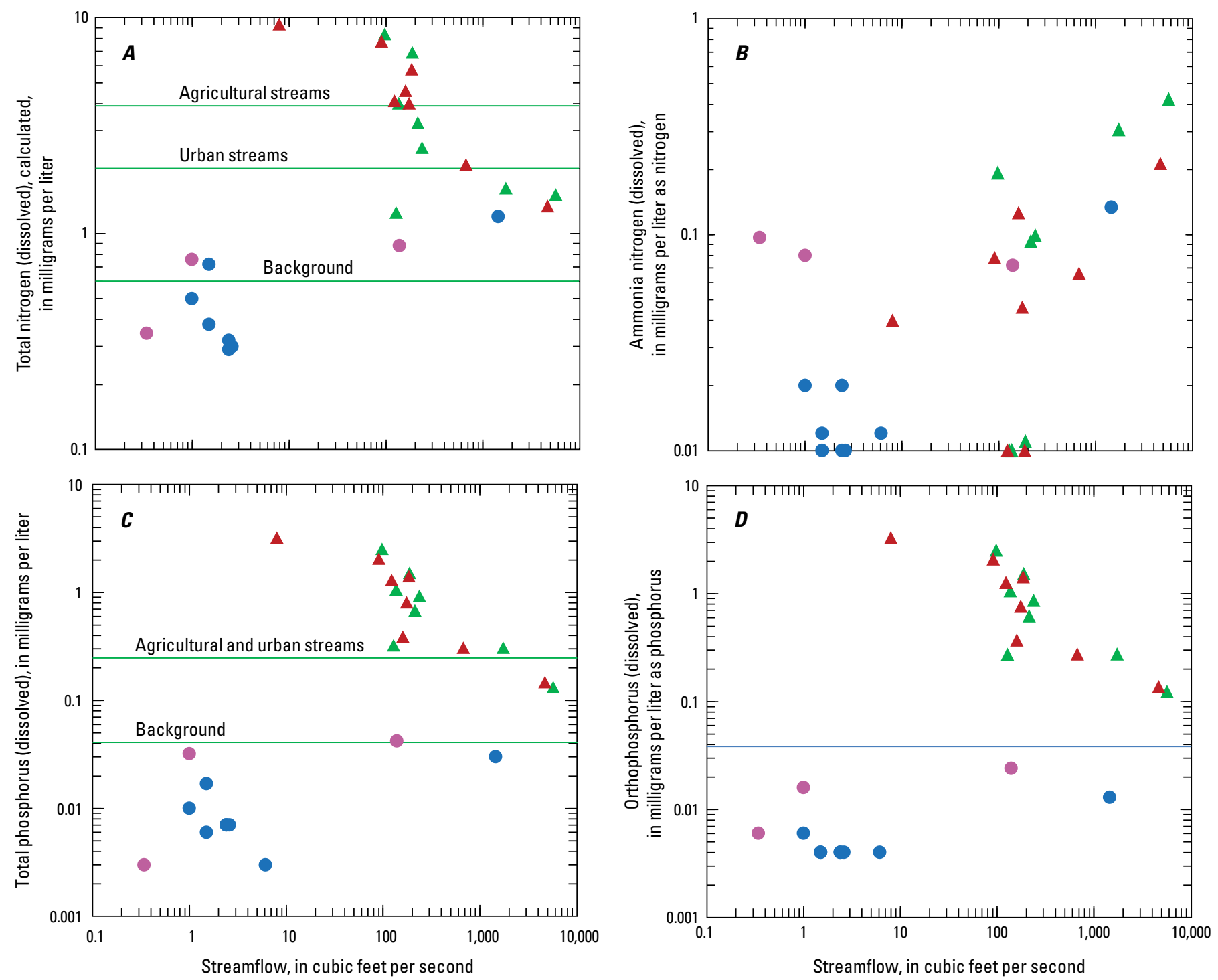

\section{EXPLANATION}

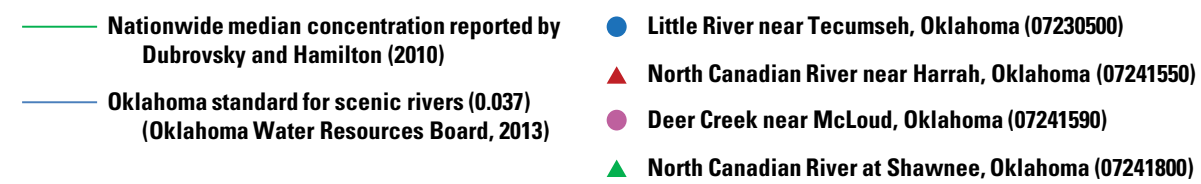

Figure 4. Nutrient concentrations measured in water samples collected at four stream sites in central 0klahoma, 2012-13, in relation to streamflow (from Becker, 2014). $A$, Total dissolved nitrogen. $B$, Dissolved ammonia nitrogen. $C$, Total dissolved phosphorus. $D$, Dissolved orthophosphorus. 

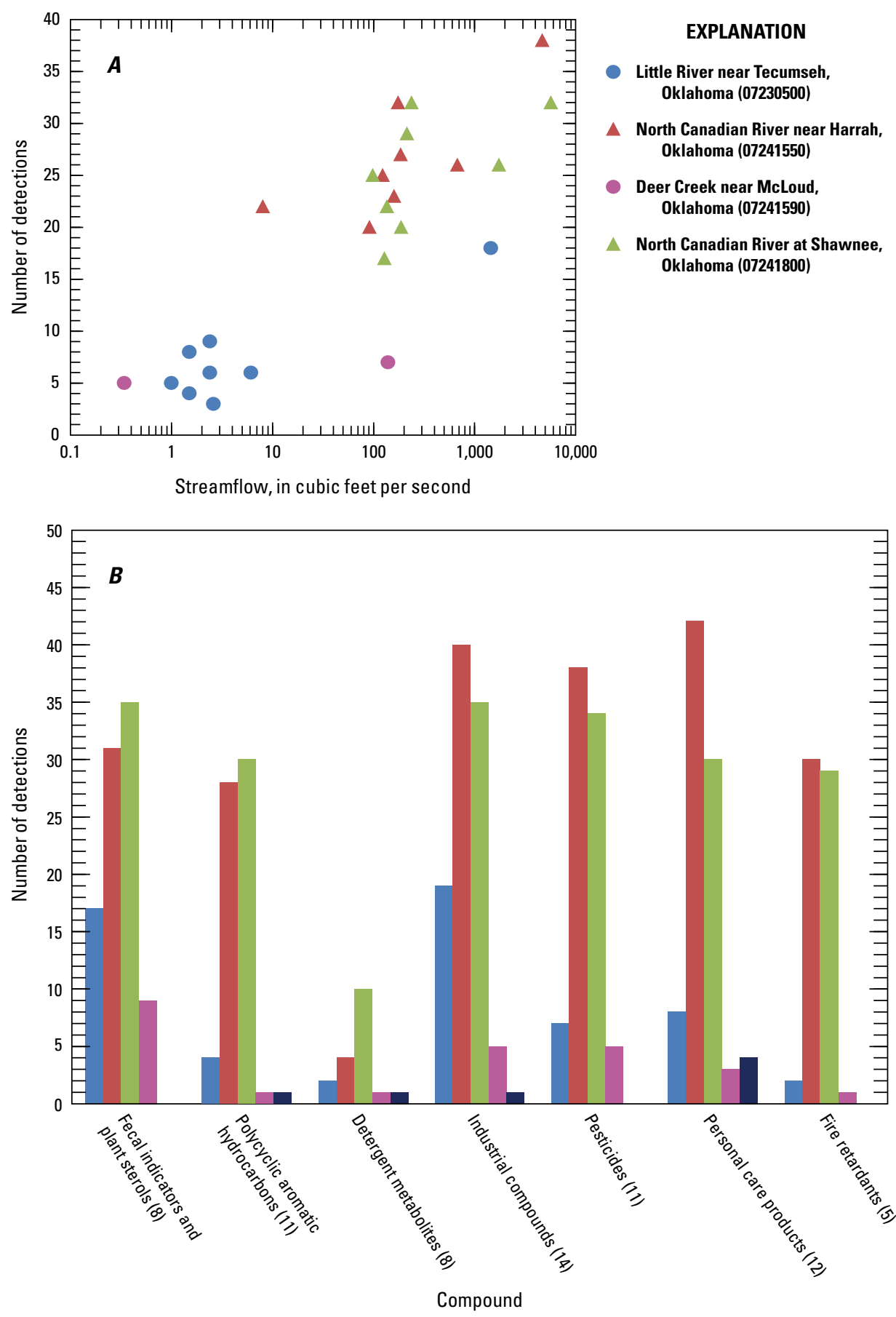

\section{EXPLANATION}

Little River near Tecumseh, Oklahoma (07230500) 8 samples collected, 59 detections

North Canadian River near Harrah, Oklahoma (07241550)

8 samples collected, 213 detections

North Canadian River at Shawnee, Oklahoma (07241800)

8 samples collected, 203 detections

Deer Creek near McLoud, Oklahoma (07241590) 3 samples collected, 25 detections

Quality-assurance equipment-blank sample 2 samples collected, 8 detections

(5) Number of compounds analyzed in category

Figure 5. Number of detections of 69 organic compounds measured in water samples collected at 4 stream sites in central 0klahoma, 2012-13, $A$, with streamflow and $B$, of categories that include fecal indicators and plant sterols, polycyclic aromatic hydrocarbons, and 5 categories of synthetic organic compounds: detergent metabolites, industrial compounds, pesticides, personal care products, and fire retardants (from Becker, 2014). 


\section{Groundwater/Surface-Water Simulations}

The USGS, in cooperation with the CPN, evaluated groundwater resources and connections between groundwater and surface water by using the MODFLOW-NWT program (Niswonger and others, 2011) for steady-state and transient simulations. By using hydrogeologic information from the numerical groundwater-flow model of the Central Oklahoma aquifer described in Mashburn and others (2013), referred to in this report as the "Central Oklahoma aquifer model," a numerical groundwater-flow model was constructed that covered the CPN Tribal Jurisdictional Area. To accomplish this task, the part of the Central Oklahoma aquifer model that covered the CPN Tribal Jurisdictional Area was refined to produce a subregional-scale numerical groundwater-flow model capable of simulating flow through alluvial aquifers, referred to in this report as the "CPN model."

The CPN model was used to estimate available groundwater resources and the effects of groundwater development and prolonged drought (fig. 6). The CPN model had a finer grid size than the Central Oklahoma aquifer model and included a layer for alluvial deposits. The CPN model had drain cells to allow groundwater to discharge to the east and had fewer layers representing bedrock aquifers than the Central Oklahoma aquifer model, with two layers in the Central Oklahoma aquifer and an additional layer representing the part of the Wellington Formation that contains saline groundwater. The CPN model was calibrated using trial-anderror and automated parameter-estimation techniques.

A higher-resolution numerical groundwater-flow model, the inset model (fig. 7), was constructed in the CPN model active area for local-scale analysis. The inset model was used to determine sustainable use of groundwater resources in two economic development zones (EDZs) by using state-of-the-art applications, including the Groundwater Management Process (Banta and Ahlfeld, 2013). Additional details about estimation of hydrogeologic properties, model features, the simulations, and model calibration can be found in Ryter and others (2015).

Model calibration was done by comparing the differences (residuals) between measurements made in the field and simulated measurements made with a model. Figure 7 shows the distribution of steady-state head residuals for all observation wells and the associated model layer for the steady-state simulation; figure 8 depicts head residuals for the transient simulation. The mean residual for groundwater heads in the steady-state model was $-1.1 \mathrm{ft}$, indicating that on average, simulated groundwater heads were $1.1 \mathrm{ft}$ higher than measured groundwater heads. For transient groundwater heads in the Central Oklahoma aquifer, the mean residual was $-1.7 \mathrm{ft}$, indicating that on average, simulated groundwater heads were $1.7 \mathrm{ft}$ higher than measured groundwater heads. The mean residual was $-4.1 \mathrm{ft}$ for transient groundwater heads in the North Canadian River alluvial aquifer. The maximum value of the root-mean-squared groundwater head residuals for steady-state and transient simulations of the Central Oklahoma aquifer and transient simulation of the North Canadian River alluvial aquifer was about 3 percent of the total groundwaterlevel relief $(450 \mathrm{ft})$, indicating that errors or inaccuracies were only a minimal part of the total model response (Anderson and Woessner, 1992). Figure 8 shows the correlation between measured and simulated groundwater-level (head) transient simulation observations. Scatter about the regression line was caused by local variations in the Central Oklahoma aquifer not included in the model, but there was a reasonable general correlation with a coefficient of determination $\left(\mathrm{R}^{2}\right)$ value of 0.98 .

The CPN model provided reasonable matches between the simulated base flow composing streamflow and estimated base flow composing streamflow at the Harrah streamflowgaging station (fig. 9A) and the Shawnee streamflow-gaging station (fig. 9B), shown as streamflow on those figures. The mean estimated base flow used in the transient model was 604 cubic feet per second $\left(\mathrm{ft}^{3} / \mathrm{s}\right)$, and the mean residual for transient base flow was $74 \mathrm{ft}^{3} / \mathrm{s}$, indicating that, on average, simulated base flow was about 12 percent less than the mean estimated base flow. This difference was caused, at least in part, by runoff peaks coming into the model from upstream and no simulated routing of runoff within the model area. The CPN numerical groundwater-flow model only affects the streamflow routed through the model by changes in base flow, which is a relatively small fraction of streamflow during peakflow periods. 


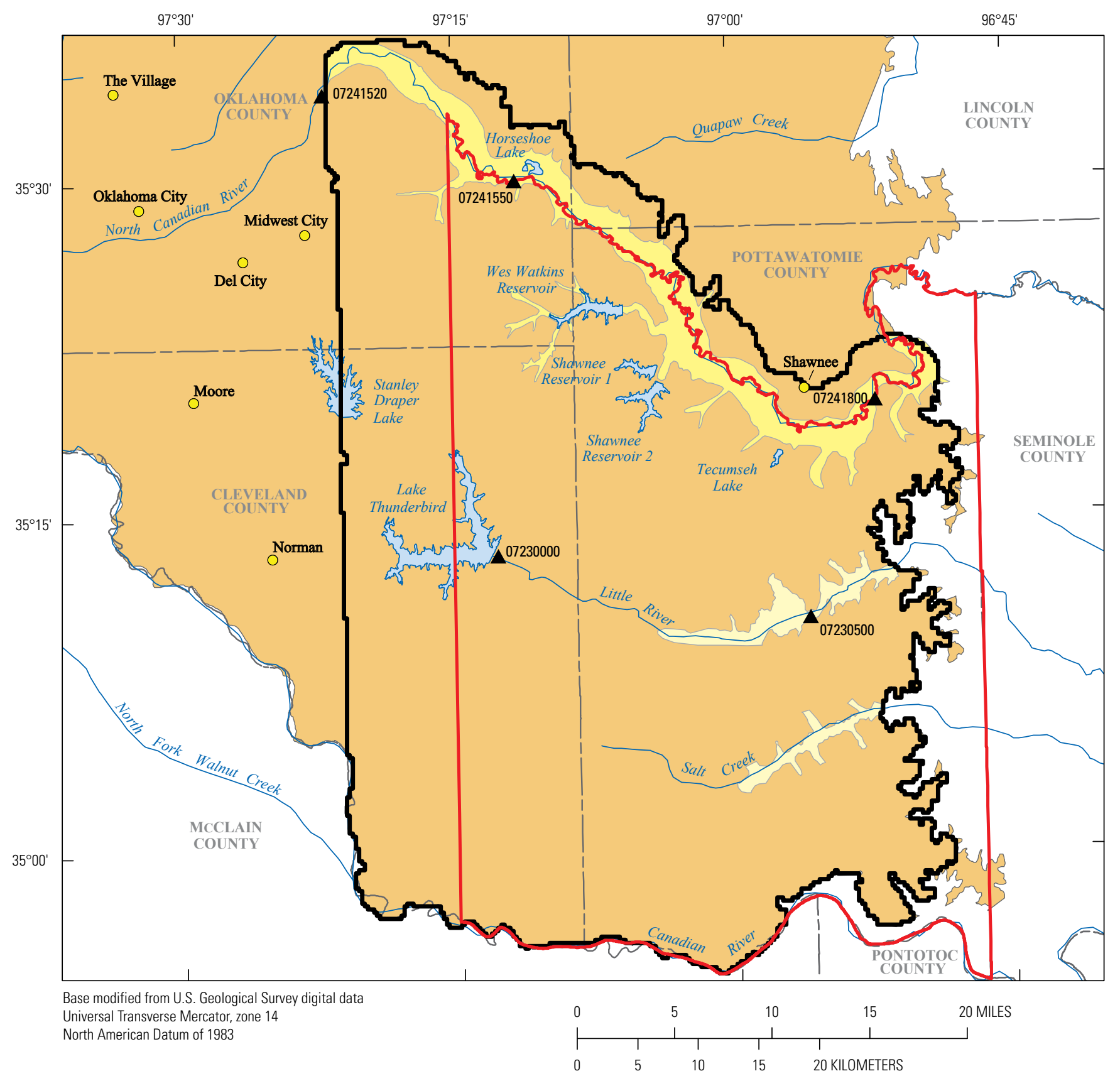

\section{EXPLANATION}

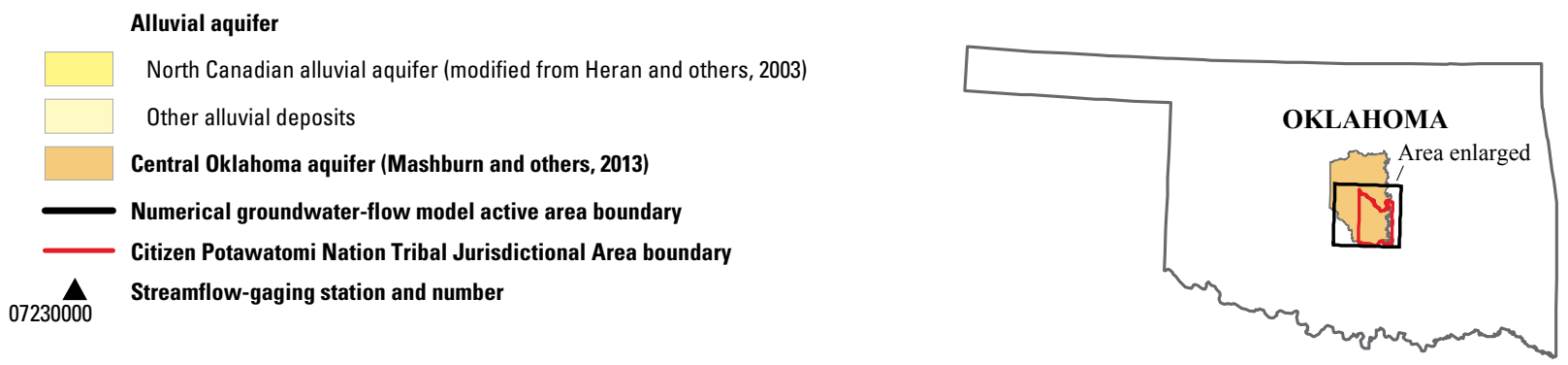

Figure 6. Location of the Citizen Potawatomi Nation Tribal Jurisdictional Area, hydrological features, and the Central Oklahoma and alluvial aquifers in central Oklahoma (from Ryter and others, 2015). 


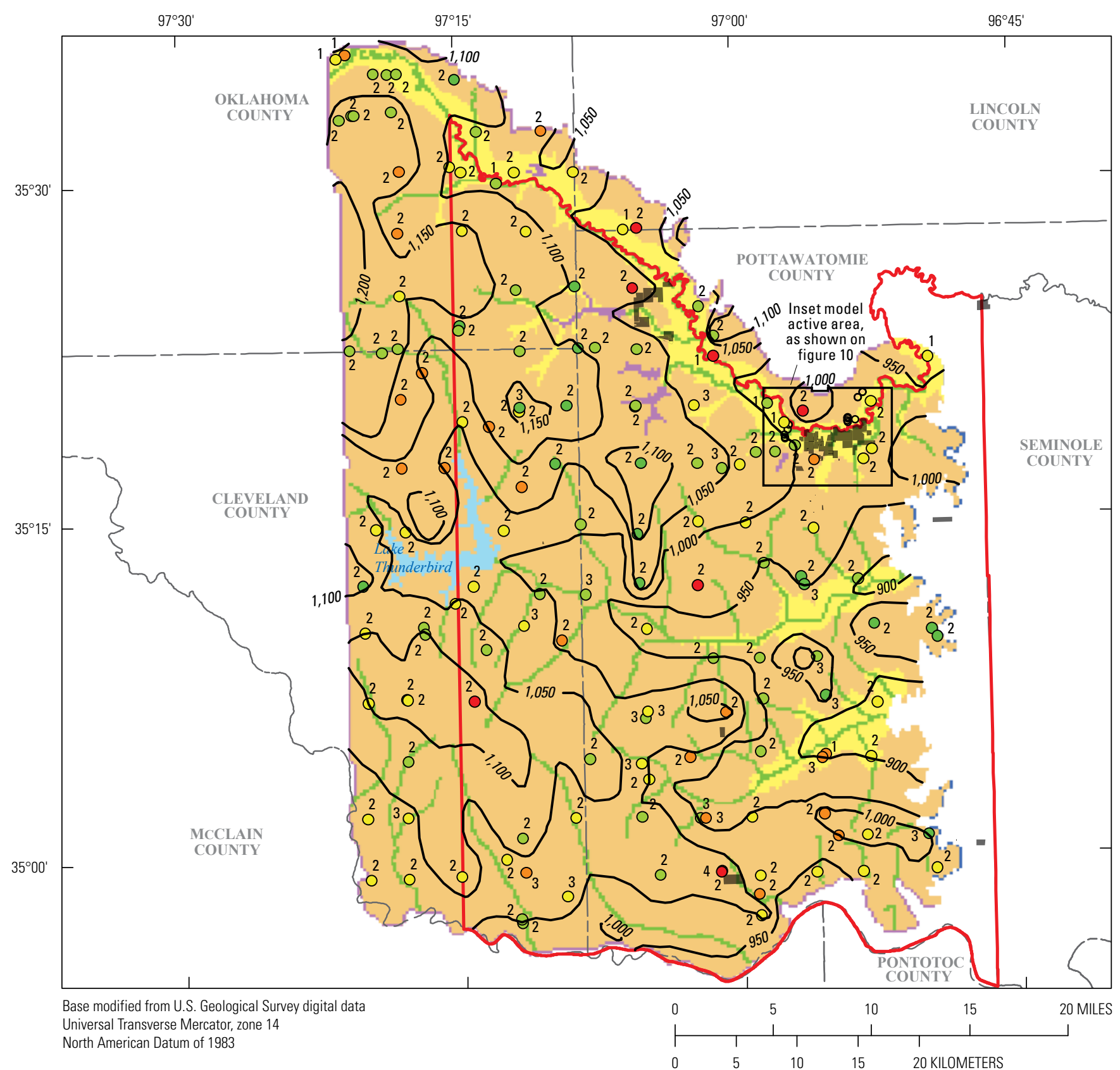

EXPLANATION

Numerical groundwater-flow model (CPN model)

Boundary condition, by cell type

Drain

General head boundary

SFR2 stream cell

Lake cell

Top active layer

Alluvial aquifer

Central Oklahoma aquifer
Economic development zone

Citizen Potawatomi Nation Tribal Jurisdictional Area boundary

- 900 - Potentiometric contour-Shows altitude at which water level would have stood in tightly cased wells, 1986-87. Contour interval 50 feet. Datum is NAVD 88 (Mashburn and others, 2013)

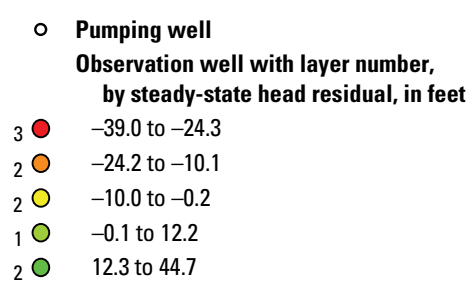

SFR2, Streamflow-routing package version 2

Figure 7. Citizen Potawatomi Nation numerical groundwater-flow model active area with the 1986-87 potentiometric surface, steadystate head residuals, locations of model features, and the inset model domain for the Citizen Potawatomi Nation Tribal Jurisdictional Area in central Oklahoma (from Ryter and others, 2015). 


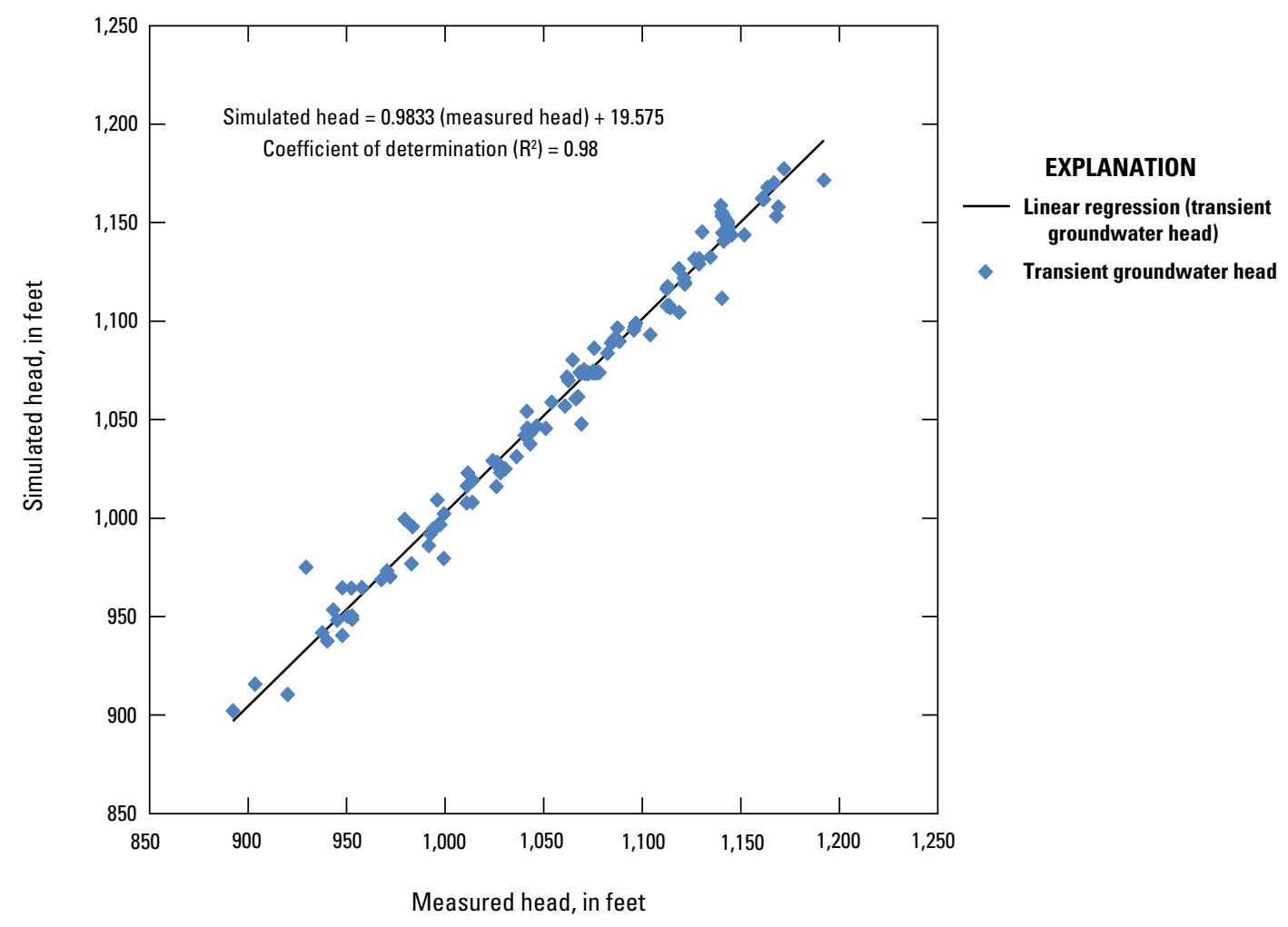

Figure 8. Transient measured groundwater heads and simulated groundwater heads for the Citizen Potawatomi Nation numerical groundwater-flow model, central Oklahoma (from Ryter and others, 2015).

Two EDZs along the North Canadian River were examined for sustainable groundwater development: the geothermal supply area and Iron Horse Industrial Park (fig. 10). Both areas are underlain by the North Canadian River alluvial aquifer, and the groundwater resources in those areas are pumped from that aquifer. The geothermal supply area required a continuous flow of $500 \mathrm{gal} / \mathrm{min}$ from one or more wells located in that area. There was no specific pumping rate desired for the Iron Horse Industrial Park - the objective of the simulation for that EDZ was to determine the amount of groundwater that could be sustainably withdrawn at that site. Water quality also was of interest at the Iron Horse Industrial Park because stream water in this area contains more total dissolved solids and chlorides, nitrogen, and organic compounds than the groundwater in these alluvial deposits (Becker, 2014); therefore, the volume of stream water entering the Iron Horse Industrial Park well field was estimated. Groundwater drawdown around the pumping wells and effects on streamflow in the North Canadian River were evaluated over the entire transient model period of 21 years; thus, the pumping rates were conservative and were less than short-term pumping rates that could be achieved by cycling pumping rates from several wells. The principal concern at these two EDZs was that head drawdown would deplete groundwater in the alluvial aquifer at an unsustainable rate. Head constraints were placed on all wells to limit the simulated head drawdown. The maximum simulated head drawdown at each of the geothermal supply managed wells was set at $16.4 \mathrm{ft}$, which was estimated to be the maximum drawdown that would not cause loss of well yield. Head constraints for the simulation at the Iron Horse Industrial Park well field allowed the head to drop as much as one-half of the predevelopment saturated thickness in the North Canadian River alluvial aquifer at each well, which was determined to be the threshold beyond which well yields would decrease at that EDZ.

Optimized pumping rates for the five wells at the geothermal supply area ranged from 98 to $201 \mathrm{gal} / \mathrm{min}$, with the combined optimized pumping rate being about $638 \mathrm{gal} /$ $\mathrm{min}$, which exceeded the goal of $500 \mathrm{gal} / \mathrm{min}$ pumping for those wells. The total pumping rate might be increased by increasing well spacing or adding wells outside of the well field, or both. 




Figure 9. Simulated and estimated streamflows for North Canadian River streamflow-gaging stations, 1988-2009 (from Ryter and others, 2015). A, Near Harrah, Oklahoma. B, At Shawnee, Okla. 


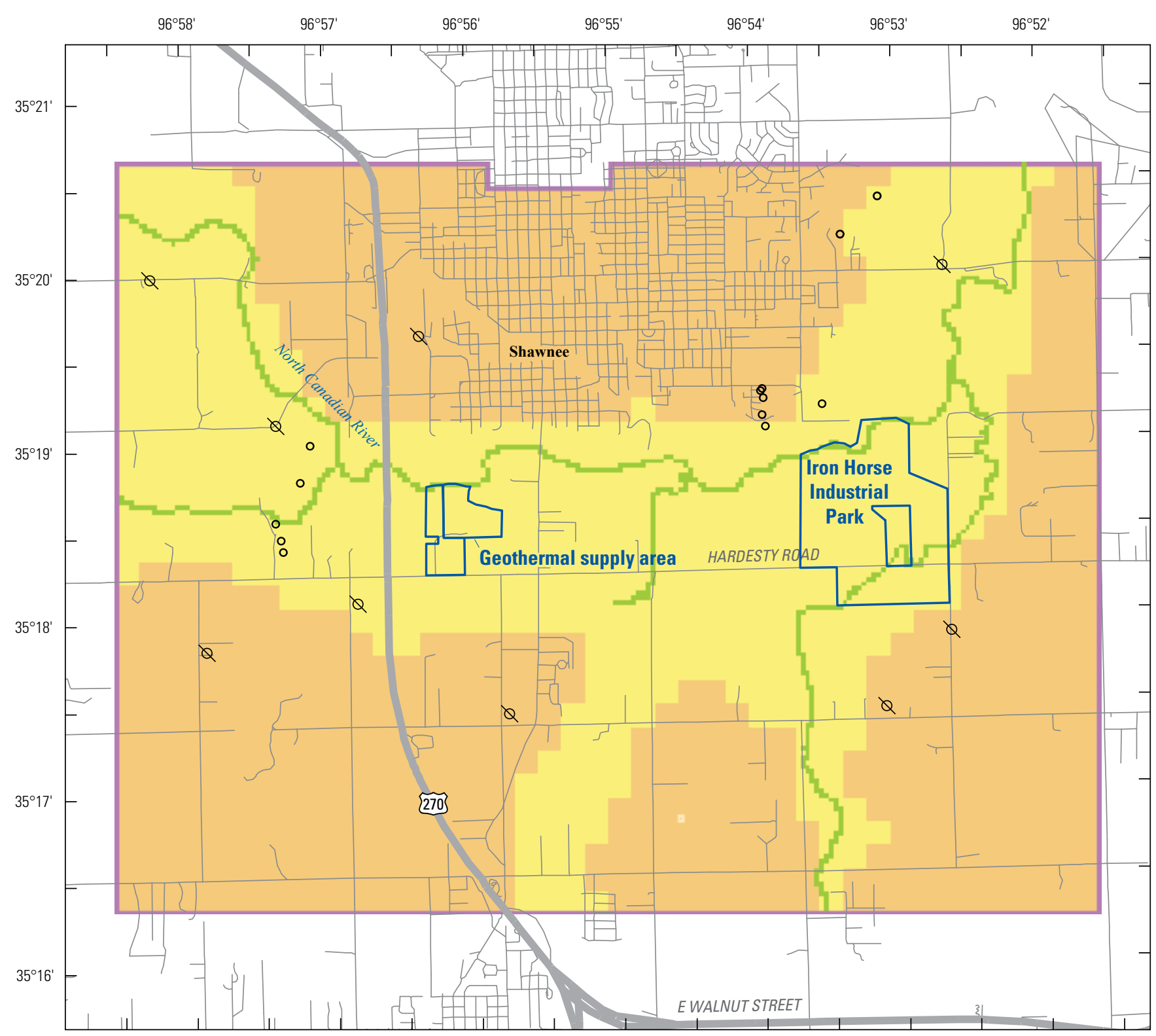

Base modified from U.S. Geological Survey digital data Universal Transverse Mercator, zone 14 North American Datum of 1983

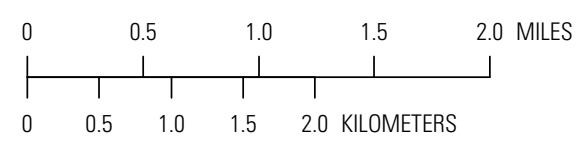

\section{EXPLANATION}

Numerical groundwater-flow model (CPN model)

Top active layer

Alluvial aquifer

Central Oklahoma aquifer

Boundary condition, by cell type

General head boundary cell

SFR2 stream cell

SFR2, Streamflow-routing package version 2

Figure 10. Inset model active area, top active layer, and boundary condition cells and locations of economic development zones simulated for sustainable yields, Citizen Potawatomi Nation Tribal Jurisdictional Area, central Oklahoma (from Ryter and others, 2015). 
Optimized pumping rates for the 16 managed wells at the Iron Horse Industrial Park ranged from 62 to $141 \mathrm{gal} /$ min, with the combined estimated optimized pumping rate at that EDZ being 1,472 gal/min. Under pumping conditions, the base flow to the North Canadian River adjacent to the Iron Horse Industrial Park well field was decreased, and the groundwater head declined to the point where stream water began to infiltrate the alluvial aquifer. Flow into and out of each stream reach defined in the inset model was calculated by the Streamflow-Routing SFR2 package (Niswonger and Prudic, 2005). Rates of induced infiltration of stream water to the aquifer at the optimal groundwater-pumping rate at the Iron Horse Industrial Park are shown for each stream reach numbered upstream to downstream on figure 11 . The total rate of induced infiltration from the North Canadian River for the optimal pumping scheme was $4.3 \mathrm{gal} / \mathrm{min}$, which was about 0.3 percent of the total pumping rate of $1,472 \mathrm{gal} / \mathrm{min}$.

To estimate the effects of drought on streamflow and groundwater storage, the CPN model was altered to simulate estimated drought conditions. There have been several severe hydrologic droughts in the study area since recordkeeping began in 1925, including the Dust Bowl drought (1929-41) and the droughts of 1952-56, 1961-72, and 1976-81 (Shivers and Andrews, 2013). The duration of these drought periods ranged from 4 years in the 1950 s to the 13 -year-long Dust Bowl. The period of this study does not include any of these historical droughts, so the effects of hypothetical drought conditions were estimated on the basis of hydrologic characteristics of recorded droughts. The years 1953 and 2011 had the largest negative departures from long-term median precipitation, with nearly 50-percent decreases from the median annual precipitation being recorded (Shivers and Andrews, 2013). Ryter and others (2015) approximated the effects of a sustained, severe drought by decreasing recharge over the entire CPN model for each stress period by 50 percent from 1990 to 2000 . Changes to the volume of groundwater in storage in the CPN Tribal Jurisdictional Area were estimated by comparing the model run under calibrated recharge conditions to the model run with hypothetical drought recharge conditions by using the "ZONEBUDGET" program (Harbaugh, 1990).

During the hypothetical drought, model recharge to the North Canadian River alluvial aquifer decreased by
441,000 acre-feet (acre-ft) and to the Central Oklahoma aquifer by 696,000 acre-ft. This decrease in recharge caused a decrease of 361,500 acre-ft of groundwater in storage $(14,100$ acre-ft or 8.6 percent in the North Canadian River alluvial aquifer and 347,400 acre-ft or 0.2 percent in the Central Oklahoma aquifer) by the end of the simulated drought. The total change in groundwater storage was approximately 0.2 percent of all groundwater in storage beneath the study area by the end of the drought period. This volume of groundwater loss showed that the Central Oklahoma aquifer is a bedrock aquifer that has relatively low rates of recharge from the land surface. Simulated base flow to streams in the model during the simulated drought decreased by 678,500 acre-ft (33 percent); base flow to the North Canadian River decreased by 386,500 acre- $\mathrm{ft}$ (37 percent); and base flow for all other parts of the CPN Tribal Jurisdictional Area decreased by 292,000 acre-ft (28 percent). Approximately 11 percent of the decrease in recharge to the North Canadian River alluvial aquifer and 66 percent of the decrease in recharge to the Central Oklahoma aquifer were offset by changes in storage and base flow to streams.

The CPN model also was used to simulate changes to streamflow in the North Canadian River during and after the drought period. Immediately after the start of the hypothetical drought, the percent change of the simulated base-flow component composing streamflow in the North Canadian River at the Shawnee streamflow-gaging station decreased because of decreased base flow and later started to rise following the relatively wet years of 1993 and 1995 until the end of the simulated drought in 2000 (fig. 12). After the simulated drought period, the percent change of base-flow composing streamflow slowly recovered through 2008 as recharge restored the amount of groundwater in storage. The largest estimated decrease in mean streamflow was 28 percent during September of 1994. Streamflow did not recover to nearnormal streamflow conditions until the wet year of 2007-7 years after the end of the hypothetical drought. The delay in streamflow recovery was caused by gradual aquifer recharge replenishing groundwater storage that had been depleted during the drought. 


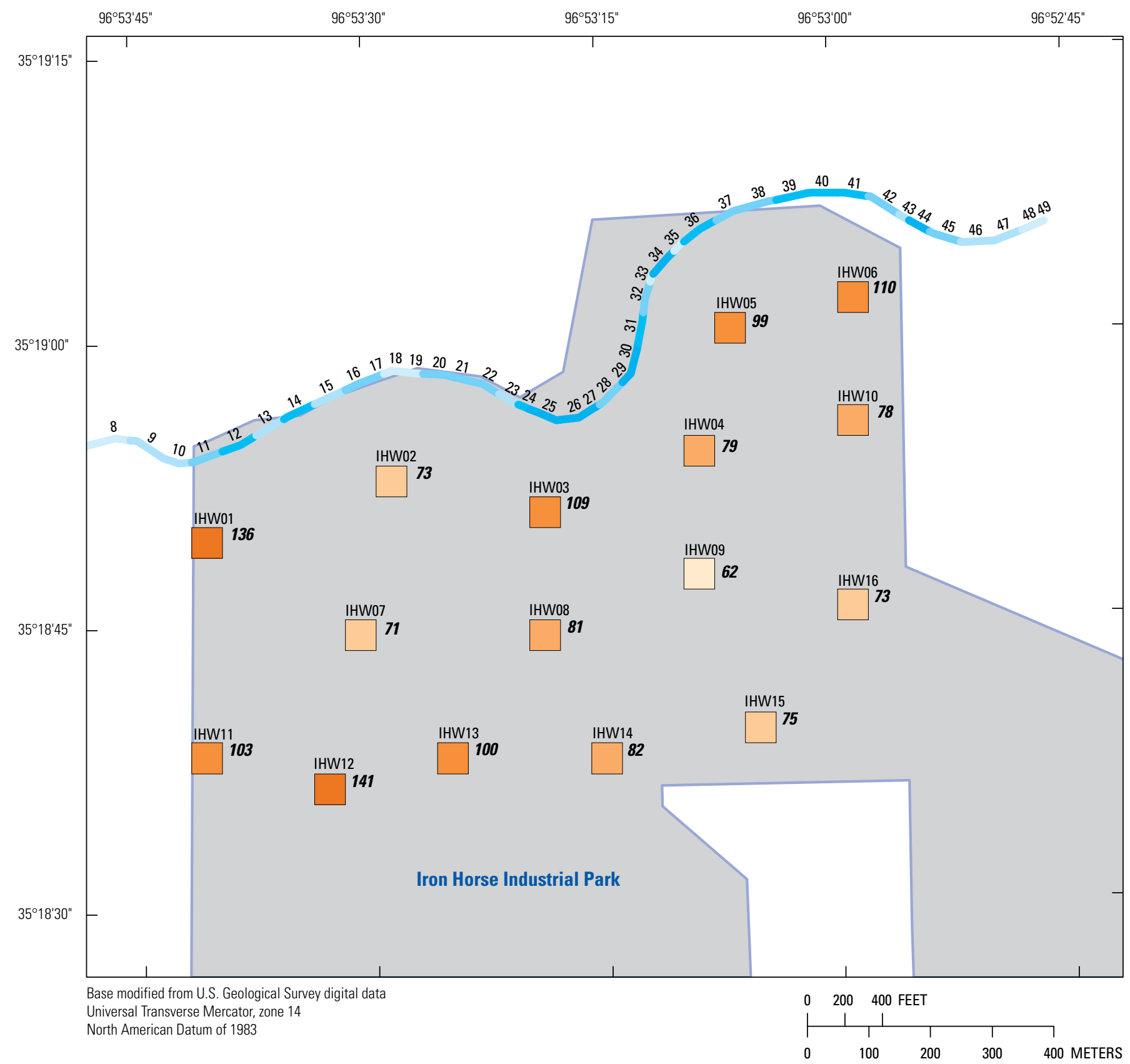

\section{EXPLANATION}

Economic development zone-Iron Horse Industrial Park (location shown on fig. 10)

Numerical groundwater-flow model cell for managed well at the Iron Horse Industrial Park, by optimized pumping rate, in gallons per minute-Well number and pumping rate are shown next to cell

62

63 to 75

76 to 82

83 to 110

111 to 141

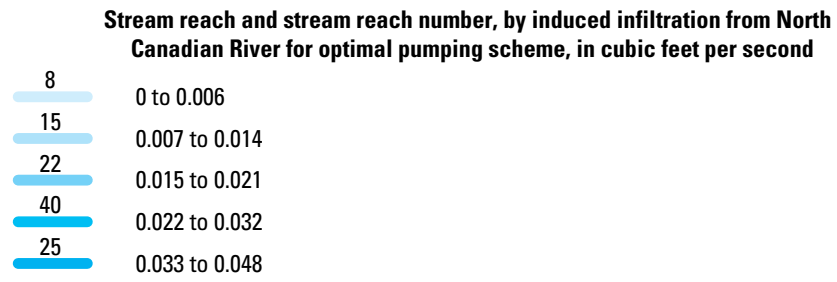

Note: Total estimated rate of optimized pumping was 1,472 gallons per minute. Total rate of induced infiltration from the North Canadian River for optimal pumping scheme was 4.3 gallons per minute ( 0.3 percent of pumping).

Figure 11. Groundwater Management Process managed wells, optimized pumping rates, and resulting effects on induced infiltration by stream reach number at the Iron Horse Industrial Park, Citizen Potawatomi Nation Tribal Jurisdictional Area, central Oklahoma (from Ryter and others, 2015). 


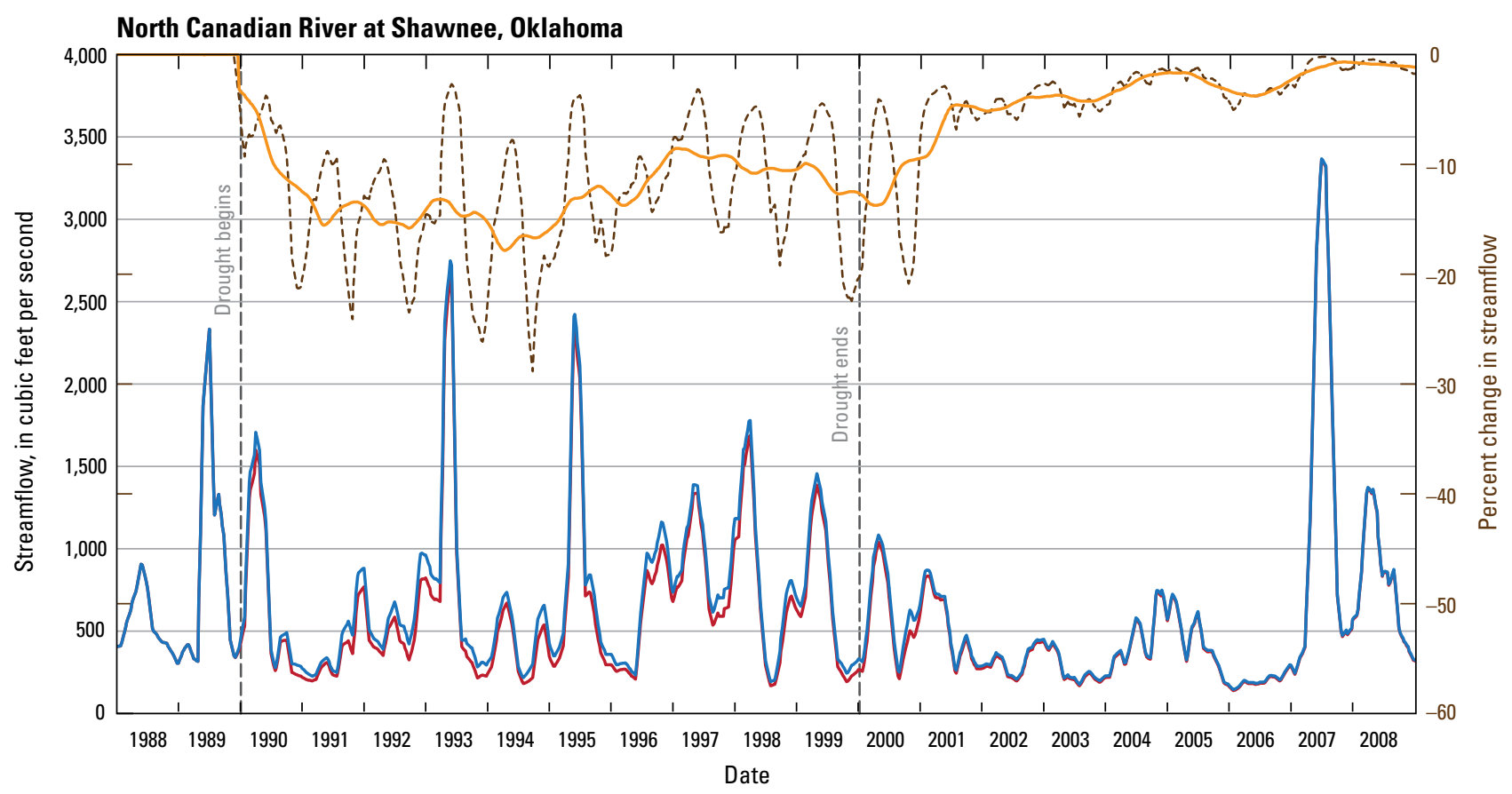

EXPLANATION

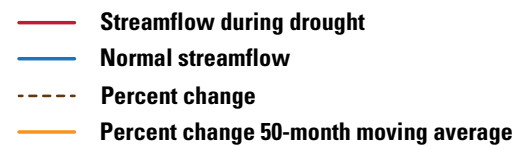

Figure 12. Normal streamflow and streamflow during a simulated drought from 1990 to 2000 at the North Canadian River at Shawnee, Oklahoma, streamflow-gaging station, with percent change during and after the simulated drought (from Ryter and others, 2015).

\section{Summary}

The U.S. Geological Survey conducted hydrologic studies and published three U.S. Geological Survey scientific investigations reports in cooperation with the Citizen Potawatomi Nation (CPN) from 2011 to 2014 to characterize the quality and quantity of water resources. The study area consists of approximately 960 square miles in parts of three counties in central Oklahoma. This study area has an abundance of water resources, being underlain by three principal aquifers (alluvial/terrace, Central Oklahoma, and Vamoosa-Ada), bordered by two major rivers (North Canadian and Canadian), and having several smaller drainages. The Central Oklahoma aquifer (also referred to as the "GarberWellington aquifer") underlies approximately 3,000 square miles in central Oklahoma in parts of Cleveland, Logan, Lincoln, Oklahoma, and Pottawatomie Counties and much of the study area. Water from these aquifers is used for municipal, industrial, commercial, agricultural, and domestic supplies.
Much of the water in the area was of good quality, though some parts of this study area had water quality impaired by very hard surface water and groundwater, large chloride concentrations in some smaller streams, relatively large concentrations of nutrients and counts of fecal-indicator bacteria in the North Canadian River, and uranium concentrations that exceeded the U.S. Environmental Protection Agency (EPA) Maximum Contaminant Level standard in water samples collected from a small number of wells. Most stream-water samples collected from the Little River by the U.S. Geological Survey in 2012-13 had dissolved solids concentrations exceeding the EPA Secondary Maximum Contaminant Level for public water supplies of 500 milligrams per liter. Concentrations of nitrogen and phosphorus compounds were substantially larger in the North Canadian River than in the Little River or Deer Creek. Most trace-element concentrations in streams were less than EPA Maximum Contaminant Levels set for public water supplies. Larger numbers of organic compounds were measured in water samples collected from the North Canadian River than from the Little River or Deer Creek. 
A numerical groundwater-flow model was constructed by using hydrogeologic information from the part of the Central Oklahoma aquifer model that covered the CPN Tribal Jurisdictional Area. The new model, termed the CPN model, estimated available groundwater resources and the effects of groundwater development and prolonged drought. The CPN model had a finer grid size than the Central Oklahoma aquifer model and included a layer to represent alluvial deposits. The CPN model had drain cells to allow groundwater to discharge to the east and had fewer layers representing bedrock aquifers than the Central Oklahoma aquifer model, with two layers in the Central Oklahoma aquifer and an additional layer representing the part of the Wellington Formation that contains saline groundwater. The CPN model was calibrated using trialand-error and automated parameter-estimation techniques.

To optimize the use of water resources at two economic development zones (EDZs) just south of the city of Shawnee, Okla., the U.S. Geological Survey Groundwater Management Process for MODFLOW was used with an inset model constructed from a part of the CPN model. Groundwater withdrawal amounts were optimized by using the Groundwater Management Process at the geothermal supply area and the Iron Horse Industrial Park. The target combined pumping rate for all wells at the geothermal supply area was 500 gallons per minute (gal $/ \mathrm{min}$ ). The Iron Horse Industrial Park required an estimate of the maximum groundwater development and the amount of North Canadian River water that may enter the wells. There were 5 managed wells used at the geothermal supply area and 16 managed wells used at the Iron Horse Industrial Park. The five managed wells at the geothermal supply area produced a maximum combined simulated flow of $638 \mathrm{gal} / \mathrm{min}$ of continuous pumping, which exceeded the $500-$ gal/min goal. At the Iron Horse Industrial Park, 16 wells had a combined sustainable pumping rate of $1,472 \mathrm{gal} / \mathrm{min}$, and only $4.3 \mathrm{gal} / \mathrm{min}$ ( $0.3 \mathrm{percent})$ of the pumped water was estimated to come from induced infiltration from the North Canadian River.

The effects of a hypothetical 10-year drought on groundwater in the CPN Tribal Jurisdictional Area and streamflow at the Shawnee, Okla., streamflow-gaging station were estimated by using the CPN model. The drought was assumed to reduce precipitation and, in turn, recharge by 50 percent for the period 1990-2000. The decrease in recharge during the hypothetical drought caused groundwater in storage over the entire model to decrease by 361,500 acre-feet (acre-ft) $(14,100$ acre-ft or 8.6 percent in the North Canadian River alluvial aquifer and 347,400 acre-ft or 0.2 percent in the Central Oklahoma aquifer), or approximately 0.2 percent of all groundwater in storage at the end of the drought period. This volume of groundwater loss showed that the Central Oklahoma aquifer is a bedrock aquifer that has relatively low rates of recharge from the land surface. The budget for base flow to the North Canadian River estimated that the change in groundwater flow to the North Canadian River decreased during the 10-year drought by 386,500 acre-ft (37 percent). In all other parts of the CPN Tribal Jurisdictional Area, base flow composing streamflow decreased by 292,000 acre-ft (28 percent). The total change in base flow composing streamflow in the model was a decrease of 678,500 acre-ft (33 percent). Simulated streamflow returned to normal rates approximately 7 years after the end of the hypothetical drought.

\section{References Cited}

Anderson, M.P., and Woessner, W.W., 1992, Applied groundwater modeling - Simulation of flow and advective transport: San Diego, London, Academic Press Inc., 381 p.

Andrews, W.J., Harich, C.R., Smith, S.J., Lewis, J.M., Shivers, M.J., Seger, C.H., and Becker, C.J., 2013, Analysis of environmental setting, surface-water and groundwater data, and data gaps for the Citizen Potawatomi Nation Tribal Jurisdictional Area, Oklahoma, through 2011: U.S. Geological Survey Scientific Investigations Report 2013-5010, 102 p. [Also available at http://pubs.usgs.gov/ sir/2013/5010/.]

Banta, E.R., and Ahlfeld, D.P., 2013, GWM-VIGroundwater management with parallel processing for multiple MODFLOW versions: U.S. Geological Survey Techniques and Methods, book 6, chap. A48, 33 p. [Also available at http://dx.doi.org/10.3133/tm6a48.]

Becker, C.J., 2014, Stream-water and groundwater quality in and near the Citizen Potawatomi Nation Tribal Jurisdictional Area, Pottawatomie County, Oklahoma, 2012-13: U.S. Geological Survey Scientific Investigations Report 2014-5178, 102 p. [Also available at http://dx.doi. org/10.3133/sir20145178.]

Bingham, R.H., and Moore, R.L., 1975, Reconnaissance of the water resources of the Oklahoma City quadrangle, central Oklahoma: Oklahoma Geological Survey Hydrologic Atlas 4, 4 sheets.

Christenson, S.C., Morton, R.B., and Mesander, B.A., 1992, Hydrogeologic maps of the Central Oklahoma aquifer, Oklahoma: U.S. Geological Survey Hydrologic Investigations Atlas HA-724, 3 sheets, scale 1:250,000.

Dubrovsky, N.M., and Hamilton, P.A., 2010, Nutrients in the Nation's streams and groundwater-National findings and implications: U.S. Geological Survey Fact Sheet 2010-3078, 6 p. [Also available at http://pubs.usgs.gov/ fs/2010/3078/.]

Fadeeva, V.K., 1971, Effect of drinking water with different chloride contents on experimental animals: Gigiena I Sanitarija, v. 36, no. 6, 11 p. 
Fry, Joyce, Xian, George, Jin, Suming, Dewitz, Jon, Homer, Collin, Yang, Limin, Barnes, Christopher, Herold, Nathaniel, and Wickham, James, 2011, Completion of the 2006 National Land Cover Database for the conterminous United States: Photogrammetric Engineering and Remote Sensing, v. 77, no. 9, p. 858-864. [Also available at http:// www.mrlc.gov/nlcd2006.php.]

Harbaugh, A.W., 1990, A computer program for calculating subregional water budgets using results from the U.S. Geological Survey modular three-dimensional ground-water flow model: U.S. Geological Survey Open-File Report 90-392, 46 p. [Also available at http://water.usgs.gov/nrp/ gwsoftware/zonebud3/ofr90392.pdf.]

Heran, W.D., Green, G.N., and Stoeser, D.B., 2003, A digital geologic map database for the State of Oklahoma: U.S. Geological Survey Open-File Report 03-247, 10 p.

Lindberg, F.A., ed., 1987, Correlation of stratigraphic units of North America (COSUNA) project, Texas-Oklahoma tectonic region: American Association of Petroleum Geologists, 1 sheet.

Maas, E.V., 1987, Salt tolerance of plants, in Christie, B.R., ed., CRC handbook of plant science in agriculture, v. II: Boca Raton, Fla., CRC Press, p. 57-75.

Mashburn, S.L., and Magers, Jessica, 2011, Potentiometric surface in the Central Oklahoma (Garber-Wellington) aquifer, Oklahoma, 2009: U.S. Geological Survey Scientific Investigations Map 3147, 1 sheet.

Mashburn, S.L., Ryter, D.W., Neel, C.R., Smith, S.J., and Magers, J.S., 2013, Hydrogeology and simulation of groundwater flow in the Central Oklahoma (GarberWellington) aquifer, Oklahoma, 1987 to 2009, and simulation of available water in storage, 2010-2059: U.S. Geological Survey Scientific Investigations Report 20135219, 92 p. [Also available at http://dx.doi.org/10.3133/ sir20135219.]

Niswonger, R.G., Panday, Sorab, and Ibaraki, Motomu, 2011, MODFLOW-NWT, A Newton formulation for MODFLOW-2005: U.S. Geological Survey Techniques and Methods 6-A37, 44 p.

Niswonger, R.G., and Prudic, D.E., 2005, Documentation of the Streamflow-Routing (SFR2) Package to include unsaturated flow beneath streams-A modification to SFR1: U.S. Geological Survey Techniques and Methods, book 6, chap. A13, 47 p.

Oklahoma Climatological Survey, 2011a, Climatological information for Pottawatomie County, OK: Oklahoma Climatological Survey, accessed December 19, 2011, at http://climate.ok.gov/index.php/climate/climate_normals by_county/my_county_or_town.
Oklahoma Climatological Survey, 2011b, Climate of Oklahoma: Oklahoma Climatological Survey, accessed December 19, 2011, at http://climate.ok.gov/index.php/site/ page/climate_of_oklahoma.

Oklahoma Water Resources Board, 2013, Data and resources, groundwater: Oklahoma Water Resources Board, accessed December 3, 2013, at http:/www.owrb.ok.gov/maps/pmg/ owrbdata_GW.html.

Ryter, D.W., Kunkel, C.D., Peterson, S.M., and Traylor, J.P., 2015, Numerical simulation of groundwater flow, resource optimization, and potential effects of prolonged drought for the Citizen Potawatomi Nation Tribal Jurisdictional Area, central Oklahoma: U.S. Geological Survey Scientific Investigations Report 2014-5167, 27 p. [Also available at http://pubs.er.usgs.gov/publication/sir20145167.]

Shivers, M.J., and Andrews, W.J., 2013, Hydrologic drought of water year 2011 compared to four major drought periods of the 20th century in Oklahoma: U.S. Geological Survey Scientific Investigations Report 2013-5018, 52 p. [Also available at http://pubs.usgs.gov/sir/2013/5018/.]

State of Oklahoma, 2006, Title 785, chapter 46Implementation of Oklahoma's water quality standards: Oklahoma Water Resources Board, unofficial 785:46, 44 p., accessed December 15, 2011, at http://www.owrb.ok.gov/ util/rules/pdf_rul/Chap46.pdf.

State of Wisconsin, 2010, Chapter NR102 - Water quality standards for Wisconsin surface waters: State of Wisconsin Register, November 2010, no. 659, 22 p.

U.S. Environmental Protection Agency, 2002, National recommended water quality criteria-2002: U.S. Environmental Protection Agency EPA-822-R-02-047, $33 \mathrm{p}$.

U.S. Environmental Protection Agency, 2011a, Secondary drinking water regulations - Guidance for nuisance chemicals: U.S. Environmental Protection Agency, accessed December 1, 2011, at http://water.epa.gov/drink/ contaminants/secondarystandards.cfm.

U.S. Environmental Protection Agency, 2011b, Drinking water contaminants: U.S. Environmental Protection Agency, accessed December 1, 2011, at http://water.epa.gov/drink/ contaminants/index.cfm.

U.S. Geological Survey, 2012, Multi-Resolution Land Characteristics Consortium National Land Cover Database: U.S. Geological Survey, accessed June 6, 2012, at http:// www.mrlc.gov.

U.S. Geological Survey, 2013, Current conditions for Oklahoma-Streamflow: U.S. Geological Survey National Water Information System-Web Interface. [Also available at http:/waterdata.usgs.gov/ok/nwis/ current?type $=$ flow\&group_key=NONE.] 


\section{Summary of USGS Studies Conducted in Cooperation with the CPN, Central Oklahoma, 2011-14}

U.S. Geological Survey, 2015, USGS water-quality data for Oklahoma: U.S. Geological Survey, accessed August 2015 at http://waterdata.usgs.gov/ok/nwis/qw/.

Wesson, L.G., 1969, Physiology of the human kidney: New York, Grune and Stratton, 719 p.
World Health Organization, 1996, Guidelines for drinkingwater quality ( $2 \mathrm{~d}$ ed.), v. 2: World Health Organization $\mathrm{WHO} / \mathrm{SDE} / \mathrm{WSH} / 03.04 / 03,94 \mathrm{p}$. 
